Article

\title{
Compassion, Self-Sacrifice, and Karma in Warfare: Buddhist Discourse on Warfare as an Ethical and Soteriological Instruction for Warriors
}

\author{
Tsunehiko Sugiki \\ Graduate School of Integrated Arts and Sciences, Hiroshima University, 1-7-1 Kagamiyama, \\ Higashihiroshima 739-8521, Japan; sugiki@hiroshima-u.ac.jp; Tel.: +81-824-24-6410
}

Received: 28 December 2019; Accepted: 29 January 2020; Published: 30 January 2020

\begin{abstract}
In premodern warrior societies, religions often provided the institutional basis for an ethics and soteriology for warriors, for whom fighting was a social role. This paper examines a Buddhist case in ancient India. I focus particularly on the discourse related to warfare in the middle-late period Mahāyāna scripture, the Satyakaparivarta, and elucidate its ethics and soteriology for kings. In the Satyakaparivarta, a king is encouraged to be a bodhisattva, who is mindful of impermanence and compassionate, who is not greedy, hateful, or delusional, and who protects sentient beings in conformity with the Ten Good Deeds. The text also teaches how a righteous king such as this, who employs warfare as a last resort to protect his people, can be saved from rebirth in hell, which occurs as a karmic retribution for his engagement in warfare. This discourse consists of elements such as compassion, self-sacrifice, and karma, which are derived from traditions both within and outside Buddhism and arranged so as to allow a king to play his role and still attain salvation. Buddhist discourse on warfare has multiple aspects. Exploring its ethical and soteriological aspect will be conducive to clarifying a form of Buddhism as a redemptive institution for warriors, which previous studies did not conduct sufficiently.
\end{abstract}

Keywords: Buddhism; compassion; self-sacrifice; karma; warfare; military; violence; soteriology; warrior; Satyakaparivarta

\section{Introduction}

One would suppose that an important function of religions is to teach their followers not to kill or injure others intentionally. However, in premodern warrior societies, where war was often a method for solving problems and warriors were required to fight, it was also an important function of religions to develop an ethics and soteriology for warriors, who may have had to kill opponents or might have been killed in battle. What do religious scriptures say in situations where their followers must fight on a battlefield?

Ancient Buddhist scriptures from India include discourses, such as instructions to warriors and narratives of exemplary Buddhist kings, that directly address issues related to warfare. This paper presents an examination of the discourse on warfare found in the Satyakaparivarta ("Chapter of 
Satyaka"), ${ }^{1}$ a Mahāyāna scripture compiled sometime between the fourth and sixth centuries $C E{ }^{2}$ and elucidates its ethics and soteriology for a king. ${ }^{3}$ Satyaka is the protagonist and preacher in this discourse. He teaches a king's ethics of rule from a Buddhist perspective, which contains a discourse on warfare, to his interlocutor, Canḍapradyota, a king of Ujjainī. ${ }^{4}$ Some other ancient South Asian texts are also examined, such as Buddhist discourses on the cakravartin, or "wheel-turner," a theological paradigm of ideal kingship, Buddhist discourses on compassionate violence, and Brahmanical discourses on the dharma of the kșatriyas (warrior-class men), in order to understand the ideological context in which the discourse in the Satyakaparivarta was developed. The Pāli scriptures used below were composed sometime between the third century BCE and the fifth century CE, and the Mahāyāna and early Vajrayāna scriptures were between roughly the first and the seventh centuries CE.

The discourse related to warfare in the Satyakaparivarta is one of the most elaborate Buddhist discourses dealing with this topic. It is also a rare text in that it explicitly states that a king who engaged in warfare in a righteous way from the Buddhist perspective expressed in the text does not acquire the negative karmic potential that a killer generally acquires through murder. ${ }^{5}$ It therefore deserves careful attention. The discourse in the Satyakaparivarta mainly deals with a war against a foreign army and not a war to put down a domestic rebellion. A king fights to protect his people from a foreign

1 The Sanskrit text is not extant. In this paper, I have used its Tibetan translation, the Derge (sde dge) recension (abbreviated to D), the Stog Palace recension (abbreviated to S), and Jamspal (2010a) (abbreviated to J). J is a critical edition based on the Derge, Peking, Narthang, Lhasa, and Stog Palace recensions, but it contains some problems, such as mistakes in transcription. Therefore, I used D and S, which I consider preserve most significant readings, as well as Jamspal (2010b) provides a loose English translation of J, which I have not used in this paper. As for Jamspal (2010b), see also Silk (2013).

In its Tibetan translation this scripture is entitled 'Phags pa byang chub sems dpa'i spyod yul gyi thabs kyi yul la rnam par 'phrul ba bstan pa zhes bya ba theg pa chen po'i mdo (the Sanskrit is Āryabodhisattvagocaropāyavisạa-vikurvānanirdeśanāmamahāyānasūtra), which I translate as "A Mahāyāna scripture entitled 'Noble Exposition of Transformative Manifestation within the Domain of Means in the Bodhisattva's Field of Activity'." Zimmermann translates this as the "Sūtra which Expounds Supernatural Manifestation [that is Part of] the Realm of Stratagems in the Bodhisattva's Field of Action" (Zimmermann 2000, p. 177); Jenkins, as "The Noble Teaching through Manifestation on the Subject of Skillful Means in the Bodhisattva's Field of Activity" (Jenkins 2010, p. 60); and Jamspal, as "The Noble Revelation of Transformational Activities by Skilfful Means in the Range of the Bodhisattva" (Jamspal 2010b, Introduction, p. xix). This text is quoted in Śāntideva's Śikṣāsamuccaya (eighth century CE), named Āryasatyakaparivarta (āryasatyake parivarte, "in the chapter of respectable Satyaka," 165.17). See also Jamspal (2010b, p. 207, note 26) and Silk (2013, p. 160). Following the Śikșāsamuccaya, I have named this scripture Satyakaparivarta in this paper because it is concise. There are two Chinese translations of this text: “佛菩薩行方便境界神通變化經” (translated by Gunabhadra, fifth century CE, Taishō Daizōkyō [abbreviated to T] 271) and “大薩遮尼乾子所經” (or “菩薩境界奪迅法門經,” translated by Bodhiruci, sixth century, T 272). The name (Ärya-)Satyakaparivarta roughly corresponds to the latter, “大薩遮尼 乾子所經." As Zimmermann (2000, pp. 177-80) argued, chapter 6 of the Tibetan translation of the Satyakaparivarta, which expounds a king's ethics of rule, is not included in the Chinese version translated by Gunabhadra and is contained in the Chinese version by Bodhiruci. A possibility exists that the chapter of royal ethics was composed between them (around the fifth-sixth centuries).

2 As for the date of compilation, see Zimmermann (2006, p. 231). See also footnote 1 in this paper.

3 In this paper, I conduct a study of thoughts, rather than a socio-historical study, since historical sources such as inscriptions are not sufficiently available to fully conduct such an investigation regarding the Satyakaparivarta.

4 The Tibetan translation of the protagonist's name is Gcer bu pa'i bu bden smra. Jamspal considers its Sanskrit to be Nirgranthaputra-Satyavādin (Jamspal 2010b) and Jenkins considers its Sanskrit to be Nirgranthaputra-Satyavaca (Jenkins 2010). As mentioned in footnote 1 above, the Śikșāsamuccaya suggests that his name in Sanskrit is Satyaka (however, no word clearly corresponds to the Tibetan smra). His original model is Niganthaputta-Saccaka, an interlocutor of the Buddha in the Pāli Cülasaccakasutta and Mahāsaccakasutta (Majjhimanikāya, $3 \overline{5}$ and 36, respectively), whose Sanskrit is Nirgranthaputra-Satyaka. Following Zimmermann (2000), in this paper I have called him "Satyaka." The title "Nirgranthaputra" suggests that he is a non-Buddhist ascetic, a Jaina monk in particular, but his discourse mostly consists of Buddhist concepts. Zimmermann (2000, p. 185) points out that such characteristic of him reflects a multireligious society in ancient India, which frames the world view of this scripture. The Tibetan translation of the king's name, Candapradyota, is Gtum po rab snang.

5 To my knowledge, the Satyakaparivarta is the only such text. Some Buddhist discourses related to warfare, such as a narrative of King Aśoka in the Aśokāvadāna (see Section 2 below), praise a pious Buddhist king or warrior engaged in warfare, but they do not articulate whether he attains rebirth in heaven after death. Some Buddhist discourses, such as a narrative of King Duțthagāmaṇi in the Mahāvaṃsa (P ed. (Geiger 1908, p. 25)), tell that a pious Buddhist king or warrior engaged in warfare attained or will attain rebirth in heaven, but they do not explicitly say whether his engagement in warfare really does not have any negative karmic effect (such as rebirth in hell) on him in some future life. According to the general Buddhist view of karma, a karmic effect may occur in some future life after the next life. Therefore, it happens that a warrior, who attains heaven in the next life, will suffer in some afterlife the negative karmic retribution for his engagement in warfare in the present life. Previous studies of Buddhist discourse on warfare did not consider this distinction fully. I will discuss these discourses in detail on another occasion. 
army, rather than to protect Buddhism from non-Buddhists who violate it. He consults both learned Brahmins and Buddhist ascetics to ascertain what is right. Thus, the text does not necessarily address a situation in which two opposing groups are connected with two religions in some way.

Some important aspects of the discourse on warfare in the Satyakaparivarta were clarified by Schmithausen, Zimmermann, and Jenkins. ${ }^{6}$ Although his discussion is concise, Schmithausen is the first to introduce this discourse to clarify an aspect of Buddhism's attitude to warfare. ${ }^{7}$ Zimmermann presented an investigation of the entire discourse, analyzed its attempt to harmonize Buddhist ethics with politics, and pointed out several elements that are derived from the Brahmanical ethics of the kṣatriyas. ${ }^{8}$ Jenkins analyzed the discourse to contextualize the Mahāyāna idea of compassionate violence found in Asanga's Bodhisattvabhümi and some other texts. ${ }^{9}$

All these studies are significant but insufficient. Previous studies did not review important differences between the discourses in the Satyakaparivarta and the discourse on compassionate violence in the Bodhisattvabhümi and other texts. Understanding the differences between these discourses is vital to understanding the discourse in the Satyakaparivarta correctly. The purpose of the discourse in the Satyakavarta should also be reconsidered. In connection with these concerns, it is also necessary to further investigate those elements of the discourse that were derived from both inside and outside Buddhism.

By exploring the kingly ethics and soteriology in the Satyakaparivarta, this paper clarifies an aspect of Buddhism that enabled the tradition to serve as a redemptive institution for warriors, which is also a challenge to previous studies and conducive to clarifying the purpose of the discourse. Many papers on the subject of Indian Buddhism dealt with discourses primarily taught to renouncers, for whom fighting in battle was not a social role. Warriors' Buddhism has not been a major research topic. Some papers investigated Buddhist discourses on warfare (including the discourse in the Satyakaparivarta), but they tended to treat the discourses as presenting Buddhist justifications or sanction for the use of warfare. ${ }^{10}$ However, Buddhist discourses on warfare have multiple aspects. The ethical rules in these discourses teach warriors how to attain salvation and do not simply explain the morality or righteousness of particular forms of warfare.

Warriors or kings played certain roles in making and ruling societies in ancient India. Warfare, as well as punishment, was a social role given to them. However, according to the general Buddhist view of karmic law, killing intentionally creates negative karma, and therefore a killer suffers its negative karmic retribution. Is it possible to save warriors, who cannot observe the precept against killing because of their social role, from suffering unhappy karmic retribution? That is a key concern (if not the sole key concern) for the authors of the Satyakaparivarta, who developed Buddhist ethical discourses on warfare.

The sections that follow in this paper are organized as follows. Section 2 investigates some Buddhist discourses on the wheel-turner and considers how those discourses are similar to and different from the Satyakaparivarta's discourse. Section 3 examines and compares three discourses of compassionate violence found in Mahāyāna and early Vajrayāna scriptures. Section 4 analyzes and elucidates the kingly ethics and soteriology of the Satyakaparivarta, drawing a comparison with the discourses on compassionate violence discussed in Section 3. These sections also include consideration of elements derived from the Brahmanical ethics for warriors. The conclusion summarizes the

6 See also footnotes 1, 2, and 4 in the present paper. The other important study is Jamspal (2010b, introduction, pp. xxxii-xlii), most of which is, however, a duplication of his loose translation of the text (see footnote 1). See also my recent publication, Sugiki (2018), in which I analyzed why a king, who is told never to punish criminals by death, is allowed to kill his enemy on a battlefield in a particular situation in the Satyakaparivarta. As for this, see also footnote 72 in the present paper.

Schmithausen (1999, pp. 52-55, especially p. 54).

8 Zimmermann (2000, pp. 199-209). As for his findings, see also Section 4 below.

9 Jenkins (2010, pp. 66-69).

10 For example, Collins (1998, pp. 419-420), Schmithausen (1999, pp. 57-59, 62), Jenkins (2010, p. 71), and most recently, Jerryson (2018, p. 18). Jerryson begins his argument to summarize the Buddhist scriptural teachings of violence (including ethical teachings of warfare) with, "The first section introduces examples from the Buddhist doctrine that provides spaces to justify violence." 
discussion and clarifies how the discourse in the Satyakaparivarta is an ethical instruction on how a king may play his role and attain rebirth in heaven.

\section{The Wheel-Turner's Conquest in the Golden Age of Dharma}

In the Pāli sutta ("scripture") entitled Rajja ("Kingdom"), the Buddha (Siddhattha) reflects on whether it is possible to exercise kingship in accordance with dhamma (dharma in Sanskrit, "righteousness") without killing and without instigating others to kill. ${ }^{11}$ The idea of the "wheel-turner" (cakkavatti in Pāli and cakravartin in Sanskrit) seems to have some connection with this Buddhist ideal of kingship. The wheel-turner is an ideal model of a king in Buddhism and is often regarded as a lay counterpart of the Buddha. He is also called "righteous dhamma/dharma king" (dhammiko dhammarājā in Pāli and dhārmiko dharmarājā in Sanskrit). The Cakkavattisīhanāda ("Lion's Roar of the Wheel-turner") describes the wheel-turner as follows. ${ }^{12}$

The wheel-turner, the righteous dhamma king, honors the dhamma and protects people and animals in conformity with it. The Buddhist standards of conduct, such as the Five Precepts (viz., not to kill, not to take what is not given, not to commit sexual misconduct, not to tell a lie, and not to drink liquor) and to avoid the Ten Bad Deeds (viz., to kill, to take what is not given, to commit sexual misconduct, to tell a lie, to speak malicious words, to speak harsh words, to speak idle talk, to be covetous, to be malicious, and to have wrong views), constitute the dhamma that he relies on. These good acts or attitudes, which are conceptualized as the Five Precepts or the Ten Good Deeds (opposites of the Ten Bad Deeds), are not exclusively Buddhist but are common among religious texts and traditions, such as the Mahābhārata in Brahmanism, in ancient India. ${ }^{13}$ The wheel-turner's dhamma is therefore not exclusively sectarian. He consults learned Brahmins as well as ascetics as to what is right to do.

The wheel-turner conquers foreign countries in the following way. First, his thousand-spoked wheel rolls to somewhere in the eastern continent and stops there. The wheel-turner takes up residence there with his fourfold army. Then, with no resistance, the rival kings in the eastern continent willingly come and surrender to him. He commands the rival kings to observe the Five Precepts and to continue to be governors of their territories. ${ }^{14}$ They then accept his command and become local rulers,

11 Rajjasutta, P ed. (Feer 1960), Samyuttanikāya, Sagāthavagga, 4.2.10.2 (p. 116, 1. 17-1. 20): atha kho bhagavato rahogatassa pațisalīinassa evam cetaso parivitakko udapādi // sakkā nu kho rajjạ̣ kāretuṃ ahanam aghātayam ajinam ajāpayạ̣ asocam asocayam dhammenāti // "Then, when the Lord was in solitude in a lonely place, a reflection arose in [his] mind thus: 'Is it possible to exercise kingship corresponding to the dhamma: without killing and without causing [others] to kill, without conquering and without causing [others] to conquer [or to confiscate], and without feeling sorrow and without causing [others] to feel sorrow?'"). See also Bodhi (2000a, p. 209) for translation.

12 Cakkavattisīhanāda (Cakkavattisīhanādasutta), P ed. (Carpenter 1947), Dīghanikāya 26 (pp. 58-79). This text tells a story of the first wheel-turner Dalhanemi and his successors, some of whom are also wheel-turners. For translation see Walshe (1987, pp. 395-405) and Collins (1998, pp. 602-15). See also Zimmermann (2006, p. 217). Collins (1998, pp. 480-96) gives a soteriological interpretation of this story: The ultimate purpose of the Cakkavattisinhanāda is to induce in its audience a sense of detachment from the passage of time in the world of transmigration and a sense that timeless nibbāna (or nirvāna) is the only significant thing to seek.

13 For example, Mahābhārata, Skt ed. (BORI), 13.13.2-5: kāyena trividhā karma vācā cāpi caturvidham / manasā trividham caiva daśa karmapathāṃs tyajet // prānātipātạ̣ stainyạ̣ ca paradāram athāpi ca / trīni pāā̄ni kāyena sarvatah parivarjayet // asatpralāpam pārușyạ̣ paiśunyam anṛtam tathā / catvāri vācà rājendra na jalpen nānucintayet // anabhidhyā parasveșu sarvasattveșu sauhṛam / karmanām phalam astīti trividham manasā caret / "There are three kinds of deed in terms of the body; four kinds in terms of the speech; and three kinds in terms of the mind. He should abandon the ten [bad] ways of deed. He should completely abandon all of the three sins with the body: murder, theft, and [having sex with] another's wife. He should not speak nor have in mind the four with the speech: false, harsh, malicious, and likewise cheating words. O King of kings! No coveting others' property; having affection for all sentient beings; and [having faith in the law of karma that] deeds bring [their respective] fruits: He should do [these] three kinds of mental [deeds]."). The Buddhist Mahāvairocana (Mahāvairocanābhisambodhivikurvitädhișthānasūtra) states that non-Buddhist practitioners and the world also observe the Ten Good Deeds or Precepts (Mahāvairocana, Chapter 18, Tib. D 494, 218r7-218v1: bcom ldan 'das 'jig rten pa mu stegs byed rnams kyang dge bcu'i las kyi lam 'di rnams yang dag par blangs te gnas lags na ... : "O Lord! Even worldly people practicing non-Buddhist traditions correctly accept and abide in these courses of Ten Good Deeds, ... ").

14 As for "to continue to be governors of their territories," the text is yathābhuttañ ca bhuñjatha (P ed. (Carpenter 1947), 6 [p. 62], 1. 19-1. 20, etc.), which Collins translates "(continue to) govern as you did before" (Collins 1998, p. 484 and p. 605). I follow Collins's interpretation, not others' interpretations such as "moderate in eating." (Collins's interpretation is also in accordance with the Satyakaparivarta's explanation of the wheel-turner's conquest. Satyakaparivarta, D 146, 103v2-v6/ S 246, 
acknowledging allegiance to him in the form of observing the Five Precepts. The same process is repeated in the southern, western, and northerrn continents. In this way, the purpose of his conquest is to make local rulers in all four continents observe the dhamma. As Schmithausen put it, ${ }^{15}$ although a wheel-turner moves his army to unconquered people, he conquers them without waging war and without killing anyone.

Vasubandhu's Abhidharmakośa ("Treasury of Abhidharma," both its kārikē, "verses," and bhāssya, "commentary," which dates to between the fourth and fifth centuries CE) includes an extended discussion regarding a wheel-turner's conquest. According to this text, there are four types of wheel-turner, viz., wheel-turners possessing wheels made of (1) gold (suvarna), (2) silver (rūpya), (3) copper (tāmra), and (4) iron (ayas) or weapons (śastra). A wheel-turner with a golden wheel conquers all four continents. Rival kings willingly come to him and become his followers. The wheel-turner in the Cakkavattisihanāda roughly corresponds to this type. A wheel-turner with a silver wheel conquers three of the four continents. He himself comes to rival kings, and then the rival kings become his followers. A wheel-turner with a copper wheel conquers two of the four continents. He comes to rival kings, quarrels with them, and then the rival kings become his followers. A wheel-turner with an iron wheel conquers only one continent. He comes to rival kings, and a fight with weapons breaks out between him and the rival kings, by which the rival kings become his followers. Like the wheel-turner in the Cakkavattisinanāda, wheel-turners (including the fourth type, who uses weapons) do not kill anyone in battle whilst in conquest, and they induce the conquered people to observe the Ten Good Deeds. ${ }^{16}$

In the Cakkavattisihanāda and some other ancient texts dealing with a wheel-turner, one can find a somewhat pessimistic view about warriors in the actual world. This is represented by two elements that characterize discourses on wheel-turners. The first element pertains to the moral status of the world where a wheel-turner can appear. According to the Cakkavattisihanāda, a king can become a wheel-turner only in an age when all people, if not perfect, voluntarily conduct themselves righteously and, as a result, are able to live to be 80,000 years old. ${ }^{17}$ The Mahāsudassanasutta (abbreviated to Mahāsudassana) includes the story of a wheel-turner named Mahāsudassana, who lived for hundreds of thousands of years. ${ }^{18}$ The Abhidharmakośa teaches that none of the four types of wheel-turner appears

62.7-63.5/ J 78.12-79.2.) Collins notes that its commentary explains the yathäbhuttañ ca bhuñjatha to concern taxation (Collins 1998, p. 485).

15 Schmithausen (1999, p. 55).

16 Abhidharmakośakārikā and -bhāṣya, Skt ed. (Pradhan 1967), 3.95-96: cakravartisamutpattir nādho 'śītisahasrakāt / suvarnarūūyatāmrāyaścakrinah te' dharakramāt//ekadvitricaturdvī̄ā na ca dvau saha buddhavat/pratyudyānasvayamyānakalahāstrajitah. avadhäh // In my translation below the English words supplemented in parentheses are based on the comments in the Bhāsya- "The wheel-turner does not appear [in ages when people's duration of life is] less than 80,000 years old. They possess wheels [made of] gold, silver, copper, and iron, [respectively]. In order from the lowest [they are conquerors of] one, two, three, and four continents, [respectively]. And, like Buddhas, two [wheel-turners do] not [appear] together [in the same age]. [They] conquer [rival kings] by coming to (pratyudyāna) (i.e., rival kings willingly come to the wheel-turner with a golden wheel to become his follower), by coming himself (svayamyanna) (i.e., the wheel-turner with a silver wheel himself comes to rival kings and makes them his follower), through quarrel (kalaha) (i.e., the wheel-turner with a copper wheel conquers rival kings through quarreling with them), and with weapons (astra) (i.e., the wheel-turner with an iron wheel conquers rival kings with weapons). [All of them conquer] without killing." See also Strong (1983, pp. 51-52).

17 Cakkavattisīhanāda, P ed. (Carpenter 1947), Dīghanikāya 26, 14 (p. 68, 1. 16-1. 18) and 24 (p. 75, 1. 19-1. 21): asītivassasahassāyukānam manussānạ̣ cattārīsạ̣ vassasahassāyukā puttā ahesuṃ. ... asītivassasahassāyukesu bhikkhave manussesu ketumatiyā rājadhāniȳā saṃkho nāma rājā uppajjissati cakkavatti dhammiko dhammarājā ... (" ... the people who lived for 80,000 years had children who lived for 40,000 years, [which happened when a new king did not give necessities to those in need and therefore could not become a wheel-turner]... O monks! When people live for 80,000 years, in the royal city of Ketumatī a king named Sankha will be born; [he will be] a wheel-turner, a righteous dhamma king, ... "). See also (Walshe 1987, pp. 400, 403)) and Collins $(1998$, pp. 608, 613) for translation.

18 Mahāsudassana, P ed. (Rhys Davids and Carpenter 1947), Dīghanikāya 17, 2.7 (p. 189, 1. 9-1. 12) and 2.13 (p. 196, 1. 3-1. 8): atha kho ānanda subhaddāya deviyā bahunnam vassānam bahunnam vassasatānam bahunnum(bahunnam) vasa(vassa)satasahassānam accayena etad ahosi: ciraditțho kho me rājā mahāsudassano,... ("Then, O Änanda, after the elapse of many years, many hundreds of years, and many hundreds of thousands of years, this occurred in [the mind of] Queen Subhaddā: 'It is really a long time since I saw King Mahāsudassana.... '"); rājā ānanda mahāsudassano caturāsītivassasahassāni kumārakīlikam kịli $i$,

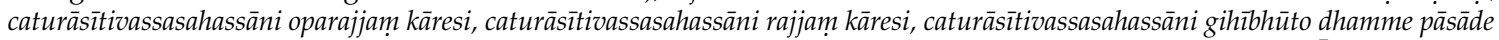
brahmacariyam cari. So cattāro brahmavihāre bhāvetvā kāyassa bhedā param maraṇa brahmalokūpago ahosi. ("O Ānanda! King 
in any age when people's duration of life is less than 80,000 years old. ${ }^{19}$ As Strong says, the function of a wheel-turner is to ensure and maintain the moral status of a world that is already moral. ${ }^{20}$ According to the Cakkavattisinhanāda, such a moral age is not realized rapidly. It comes after many successive ages when more and more people gradually reflect on their deeds and come to act righteously and, as a consequence, their lifespan gradually increases. ${ }^{21}$ One can speculate that this is a good explanation of why the wheel-turner can conquer foreign powers without killing: As kings in foreign countries also conduct themselves righteously, they do not aspire to kill in battle and instead accept the commands, indeed the guidance, of the wheel-turner as the most righteous ruler. ${ }^{22}$

The second element pertains to a king's salvation after death. In the Cakkavattisìhanāda, every wheel-turner upon retirement abandons lay life and becomes a homeless renouncer to attain heavenly pleasure after death. ${ }^{23}$ In the Mahāsudassana, the wheel-turner Mahāsudassana is not stated explicitly to have become a renouncer. Instead, in the last 84,000 years of his life, he was intent on the practice of the Four Immeasurables (viz., to develop a mind of immeasurable mercy, compassion, empathetic joy,

Mahāsudassana indulged in boyish sports for 84,000 years, he exercised the viceroyalty for 84,000 years, he exercised kingship for 84,000 years, and, being a layman, he performed the practice of chastity in the Dhamma Palace for 84,000 years. Having performed the Four Brahman-abodes, after death with the breakup of the body he was reborn in the world of Brahman.") See also Walshe (1987, p. 288 and p. 289) for translation. Mahāsudassana is the Buddha in one of his past lives. The text does not mention clearly the duration of life of common people in the age of Mahāsudassana. However, considering his queen's duration of life mentioned in the passage quoted above (hundreds of thousands of years), it seems that common people also lived a very long time during that age.

19 Abhidharmakośakārikā and -bhāssya, Skt ed. (Pradhan 1967), 3.95ab. As for its text and translation, see footnote 16 in the present paper.

20 Strong (1983, pp. 45-46, 49).

21 Cakkavattisīhanāda, P ed. (Carpenter 1947), Dīghanikāya 26, 21-22 (p. 73, 1. 3-p. 75, 1. 3): dasavassāyukesu bhikkhave manussesu sattāham satthantarakappo bhavissati, te aññamañnam migasañnam pațilabhissanti, ... te tịnhena satthena - esa migo esa migo ti añ̃amaññạ̣ jūvitā voropessanti. atha kho tesam bhikkhave sattānạ̣ ekaccānam evam bhavissati - mā ca mayam kañci, mā c'amhe koci, ... atha kho tesam bhikkhave sattānam evam bhavissati — mayạ̣ kho akusaiānam dhammānam samādānahetu àyatam ñätikkhayạ̣ pattā, yan nūna mayạ̣ kusalạ̣ kareyyāma. kim kusalạ̣ kareyyāma? yan nūna mayam pānāâtipātā virameyyāma, idạ̣ kusalạ̣ dhammam samādāya vatteyyāmäti ... te kusalānam dhammānam samādānahetu āyunā pi vadḍhassanti vannena pi vaddhissanti....

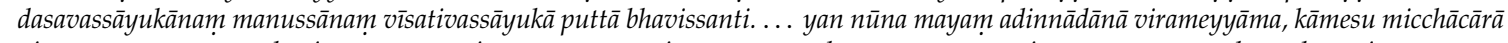
virameyyāma, musāvādā virameyyāma, pisunāya vācāya virameyyāma, pharusāya vācāya virameyyāma, samphappalāpā virameyyāma, abhijjham pajaheyyāma, vyāā̄ạ̀ pajaheyyāma, micchādiț̣hị̣ pajaheyyāma, tayo dhamme pajaheyyāma adhammarāgam visamalobhạ̣

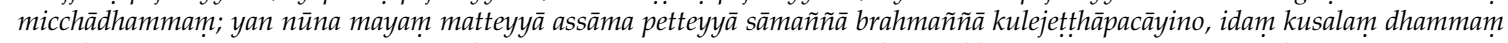

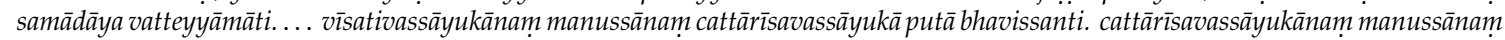

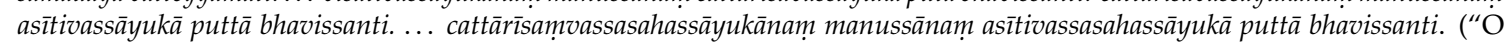
monks! When people live [only] for ten years, there will be a seven-day period of 'sword-interval.' They will think each other as wild animals [or deer].... With [their] sharp sword, thinking 'He is an animal! He is an animal!' they will kill each other. However, O monks, this [thought] will occur in some of those sentient beings: 'Let us not [kill] anyone, let anyone [not kill] us! ...' ... Then, O monks, this [thought] will occur to those sentient beings: 'As we took the [path of] bad deeds, we have so long experienced the loss of [our own] relatives. What if we do good? What good [things] should we do? Why don't we abstain from killing? Let us take this good deed and go on.' ... Because of [their] taking good deeds, they will increase life-span and will also increase beauty.... The people living for ten years will have children living for twenty years. ... '... Let us abstain from taking what is not given; abstain from sexual misconduct; abstain from telling lies; abstain from malicious speech; abstain from harsh speech; abstain from idle chatter; renounce covetousness; renounce ill-will; and renounce wrong view. Let us renouce three deeds: improper desire, iniquitous greed, and wrong practice. Let us respect [our] mothers and fathers, ascetics and brahmins, and the elders of [our] families. Let us take this good deed and go on.' ... The people living for twenty years will have children living for forty years. The people living for forty years will have children living for eighty years. ... [In this way children have longer live-span] ... The people living for 40,000 years will have children living for 80,000 years.") See also Walshe (1987, pp. 402-3) and Collins (1998, pp. 610-12) for translation.

22 My interpretation presented here is different from that of Collins (1998, pp. 485-86), who introduces an interpretation of the wheel-turner's warless conquest found in the Sumañgalavilāsin̄ as a commentary on the Mahāsudassana: Rival kings surrender to the wheel-turner without fighting for resistance because they know that no one can defeat him by force of arms, and after surrender, only the wise, not everyone, in the conquered territory accept his command. However, the commentary's interpretation does not take fully into consideration the discourse that all people are morally good in the age when a wheel-turner appears. It seems to be an interpretation from a somewhat realist viewpoint.

23 Cakkavattisīhanāda, P ed. (Carpenter 1947), Dīghanikāya 26, 3 (p. 59, 1. 31-p. 60, 1. 9), etc: 'bhuttā kho pana me mānusakā kāmā, samayo dibbe kāme pariyesitum. ... ' atha kho bhikkhave rājā dalhanemi jeț̣haputtam kumāram sādhukam rajje samanusāsitvā, kesamassum ohāretvā, kāsāyāni vatthāni acchādetva, agārasmā anagāriyam pabbaji. ("'I have enjoyed human pleasures. Now is the time to seek heavenly pleasures.... 'Then, O monks, having installed [his] eldest son the prince thoroughly as a king, King Dalhanemi shaved off his hair and beard, put on yellow robes, and went forth from home to homelessness." [Wheel-turners after Dalhanemi also do the same after retirement.]) See also Walshe (1987, p. 396) and Collins (1998, p. 603) for translation. 
and equanimity) and attained rebirth in the world of Brahman (brahmaloka). ${ }^{24}$ The wheel-turners were born in the golden age of dhamma and were hence able to rule others and live their lives in accordane with dhamma. Even such morally flawless kings needed to become renouncers or to be intent on practicing the Four Immeasurables for long years to realize rebirth in heaven.

However, ancient India was not so morally utopian. People often did not act righteously, and armed conflicts frequently broke out among different groups. The authors of the Aśokāvadāna ("Aśoka's Legend"), which is a narrative of the life of King Aśoka (third century BCE) of the Maurya Dynasty, were fully aware of it. The Aśokāvadāna presents a somewhat different idea of a wheel-turner. In this narrative Aśoka is called balacakravartin ("armed wheel-turner"), caturbhāgacakravartin ("wheel-turner [who conquers only] one of the four [continents]"), and dhārmiko dharmarājā ("righteous dharma king"). He has some aspects in common with the wheel-turner with an iron wheel in the Abhidharmakośa mentioned earlier, but they are different in the following two respects: (i) Aśoka, an armed wheel-turner, was born in the ancient age in India, when people were not always moral. (ii) He had to kill opponents on some occasions to attain his sovereignty over one continent. ${ }^{25}$ The authors assigned the title "wheel-turner" (with the term bala, or "armed" in this context) to the historical king perhaps to emphasize his greatness and morality as an exemplary Buddhist king. However, they could not depict him as the one who could conquer the whole continent without killing anyone in war. (In fact, historical Aśoka killed many especially before conversion, as is well known from his inscriptions.) Interestingly, the Aśokāvadāna does not articulate whether Aśoka could attain rebirth in heaven or any other happy destination after death. (The term "wheel-turner" below in this paper indicates the wheel-turner in the golden age of dharma and not the armed wheel-turner depicted in the Aśokāvadāna.)

In the Satyakaparivarta, a king is never called "wheel-turner" (nor "armed wheel-turner"). As examined in Section 4 below, the Satyakaparivarta teaches that a king in the actual world (ancient India) should observe and rule in conformity with the Ten Good Deeds and consult learned Brahmins and Buddhist ascetics for moral advice. The attitudes that a king should adopt, according to the Satyakaparivarta, are similar to elements of the wheel-turner's rule mentioned above. However, a king's attitude about warfare in the Satyakaparivarta is different from the wheel-turner's: The latter's conquest without killing could not fully be a model for a king's conquest in the actual world, which had morally degenerated. Thus, from a realistic viewpoint, ancient Buddhist scriptures (including the Satyakaparivarta) needed to include teachings to save warriors. What do Buddhist scriptures teach about saving them?

24 Mahāsudassana, P ed. (Rhys Davids and Carpenter 1947), Dīghanikāya 17, 2.13 (p. 196, 1. 6-1. 8). See footnote 18 in the present paper.

25 For example, Aśokāvadāna, Skt ed. (Mukhopadhyaya 1963), p. 41, 1. 17-p. 42, 1. 1. 11: susìmenāpi śrutam bindusāro rājā kālagato 'śoko rājye pratiṣthitah / iti śrutvā ca ruṣitam (ruṣitạn) abhyāgatah / tvaritan ca tasmād deśād āgatah / aśokenāpi pātaliputre nagare ekasmin dvāre eko nagnah sthāpitah / dvitìiye dvitīyas tritīye rādhaguptah pūrvadvāre svayam eva rājāsoko 'vasthitah /... paritaś

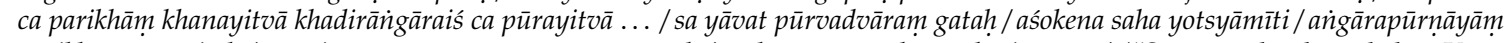
parikhāyām patitah / tatraiva cānayena vyasanam àpannah / yadā ca susīmah praghātitas ... / "Susīma also heard that King Bindusāra had died and Aśoka had been enthroned. Thus heard, he got furious and hastily returned [to the capital] from that place. Meanwhile, in Pātaliputra, Aśoka deployed a naked [warrior] at the first gate of the city, the second [warrior] at the second [gate], and Rādhagupta at the third [gate], and King Aśoka himself stood at the east gate.... And all around [Rādhagupta] dug a ditch, filled [it] with charcoal of acacia wood,... He (Susīma) arrived at the east gate with an intention to fight in battle against Aśoka. He (Susīma) fell into the ditch full of charcoal, and just in that [ditch] he got an evil result unfortunately. And when Susīma was [thus] killed, ... "). See also Strong $(1983,209-10)$ for translation. Although it is not in war, Aśoka killed many hundreds of opponents by punishment even after he became "Dharma-Aśoka." As for this see Jenkins (2016, p. 150). Strong (1983, pp. 52-53) focuses on the similarity between the wheel-turner with an iron wheel in the Abhidharmakośa and Aśoka in the Aśokāvadāna, but the differences between them that I mentioned should not be ignored. 


\section{Compassionate and Self-sacrificial Killing}

Several answers to the question presented above can be found in Buddhist scriptures. ${ }^{26}$ One answer is that warriors with an evil intention to kill opponents in battle are reborn in hell. The Brahmanical Smrti literature, such as the Mahäbhārata, includes the teaching that a warrior who is killed on a battlefield while struggling in battle is reborn in heaven. ${ }^{27}$ Opposing this, in the Pāli scripture entitled Yodhajjīoa (name of a warrior), the Buddha teaches that a warrior who is killed while struggling in battle is reborn in hell, not in heaven, because of his "inferior, depraved, and misdirected intention" (cittam ... hinam duggatam duppanihitam) to kill his enemy in battle. ${ }^{28}$ The bad intention to kill is the determinative factor for the warrior's unfavorable circumstances of rebirth after death. Is it then possible for a warrior to kill in battle while maintaining a good state of mind, and in so doing, to attain a good rebirth? Gethin says that according to the Pāli Abhidhamma scriptures, it is impossible for anyone to kill a living being with a good state of mind. The intention to kill a living being invariably involves some form of hatred-a bad state of mind. ${ }^{29}$

However, in Buddhism, there is also the idea that one can kill others while maintaining a good or neutral state of mind. Such a killer is not reborn in hell if he also satisfies the other prescribed requirements. Some Buddhist scriptures in the Mahāyāna tradition address a bodhisattva's (or Mahāyāna practitioner's) compassionate and self-sacrificial killing as a skill in means, ${ }^{30}$ which is carried out as the last resort to benefit others and which ultimately benefits both oneself and others. In this paper, that is designated as "compassionate and self-sacrificial killing." 31 This is a form of

26 Buddhist scriptures also teach three ways to save warriors from killing opponents in war, by which they do not acquire the negative karmic potential leading to rebirth in hell. They are (1) to retreat completely from the role of warrior, (2) to solve problems with rival kings without resorting to war, and (3) to not kill enemy warriors while fighting in battle. The second and third ways acknowledge the warrior's role in settling problems with opponents as far as he does not kill the opponents. I will discuss these in detail on another occasion.

27 Hara (2001) examines teachings found in the Brahmanical Smrti literature on the virtues and fates of warriors who were wounded or killed in battle: Wounds that one incurs by enemies in battle are bodily ornaments of the heroic warriors; dying with his body woundless is not praise-worthy; the blood from his wounds purifies the heroic warrior from all sins that he committed in the past, and enduring the pains from wounds is the highest asceticism (tapas) for him; it is a warrior's ideal that he dies on a battle-field being seriously wounded by his enemy's weapons; to die in battle is his highest dharma or duty; if one wins the battle, one gains the enemy's territory, and if he is killed, he is promised to attain heaven (and dying in Kurukșetra is particularly rewarding); warriors slain by the enemy's weapon are termed as śastra-püta (purified by a weapon), and being sanctified by a weapon, they attain heaven (the enemy's weapon annihilates his sins); warriors are expected to die on a viraśayana (also called vìrasevitaśayana, "a bed of a hero," viz., a bed of arrows with a pillar of arrows) on a battle-field; a wounded heroic warrior refuses surgeons' treatment and being taken home; it is condemned for him to die at home; and, according to the Medhātithi, if the king cannot die in battle, he may burn or drown himself, and Kullūla says that he may kill himself by starvation.

28 Yodhājìva, P ed. (Feer 1960), Samyuttanikāya, Salāyatanavagga, 8 (42), 3, 6 (p. 309, 1. 4-1. 9): yo so gāmani yodhājī̃o sañgāme ussahati vāyamati // tassa tạ cittam pubbe hīnạ̣ duggatam duppanihitam ime sattā hañ̃antu vā bajjhantu vā ucchijjantu vā vinassantu vā mā ahesum iti vī ti // tam enam ussahantam vāyamantam pare hananti pariyāpādenti // so kāyassa bhedā param maranā sarāijitā nāma nirayā tatthupapajjati // ("O headman! If he, as a warrior, strives and exerts himself in battle; if his mind is already inferior, depraved, and misdirected [with the thought] 'Let these sentient beings be killed, bound, annihilated, perished, or never exist'; and then if others kill him and finish [him] off [while he is] striving and exerting himself [in battle], then, after death with the breakup of the body he is reborn in the hell named Sarājita.'”) See also Bodhi (Bodhi 2000b, pp. 1334-35) for translation. Schmithausen (1999, pp. 48-49) points out that a similar idea can be found in multiple texts, such as the Abhidharmakośa: A warrior with an intention to kill in battle is sinful even if he was conscripted and even if the purpose of his battle is to defend himself, his friends, and his country from invaders. See also Gethin $(2007$, p. 72).

29 Gethin (2004, p. 189; 2007, pp. 70-71).

30 The "skill in means," the Sanskrit for which is upāyakauśalya and which is also expressed by scholars as "skillful means," is an important concept in Mahāyana. There are various forms and views of skill in means, but it basically means the effective compassionate practices of a bodhisattva that benefit the bodhisattva and others.

31 My phrase "compassionate and self-sacrificial killing as a skill in means, which is carried out as the last resort to benefit others and which ultimately benefits both oneself and others" is coined from a line (snying rje chen po de dang thabs mkhas pa des, "because of that great compassion and that skill in means") in the Upāyakausáilya (Tib. D 261, 305r7-v1) and is derived from consideration of the content of this practice. This form of compassionate violence was studied by many scholars such as Tatz, Fujita, and recently Jenkins. See footnotes 34,37 , and 38 in the present paper. 
Buddhist compassionate violence, ${ }^{32}$ and such compassionate and self-sacrificial killing takes different forms, not all of which are meant for warriors and the roles they must play.

As is well-known, the oldest and most influential discourse addressing compassionate and self-sacrificial killing is the narrative of a ship captain named Greatly Compassionate (snying rje chen po dang ldan pa, who is a one of the Buddha's past lives) ${ }^{33}$ found in the Upāyakauśalyasūtra (abbreviated to Upāyakauśalya, "Skill in Means," one of the earliest Mahāyāna scriptures). The outline is as follows. ${ }^{34}$

Once upon a time, five hundred merchants set sail on the sea in search of wealth. Among the passengers was a robber, who intended to kill the merchants and steal their wealth. The captain of the ship, Greatly Compassionate, is informed of this by the sea gods in a dream. He is also told that because the merchants are all bodhisattvas progressing toward enlightenment, the robber will be reborn and remain in the great hell until they all attain enlightenment, as karmic retribution for killing them. Captain Greatly Compassionate considers the matter for seven days and reaches the conclusion that he should kill the robber: It is the only way to save them all. He realizes that if he informs the merchants of the robber, they will kill him with bad states of mind and will themselves be reborn in hell for that deed, but if he himself kills the robber, although he will be reborn in the great hell repeatedly for one hundred thousand kalpa ("eons"), he can prevent the merchants from being murdered and prevent both the robber and merchants from committing a murder that will earn them all rebirth in hell. Consequently, out of compassion for both the robber and the merchants, the Captain intentionally (ched du bsams te) ) $^{35}$ killed the robber with a short spear. Because of his great compassion and his skill with the means of killing with a spear (snying rje chen po de dang thabs mkhas pa des), ${ }^{36}$ the round of rebirths for the Captain was curtailed by one hundred thousand kalpa, and the robber was reborn in heaven. The five hundred merchants became Buddhas in the auspicious kalpa.

In his Bodhisattvabhūmi ("Bodhisattva Stage," composed in the fourth century CE), Asanga explains particular cases in which a bodhisattva is neither sinful nor transgressive (anāpattiko) but rather quite meritorious (bahu punyam) for having transgressed the first seven of the Ten Good Deeds with the skill in means to benefit others while doing so. ${ }^{37}$ In order to explicate a case in which the precept

32 Herein, I collectively label all forms of Buddhist violence entirely or partially motivated by compassion, "compassionate violence." A form of it is the "compassionate and self-sacrificial killing," which I distinguish from another form of compassionate violence, the compassionate killing without a strong factor of self-sacrifice (which can be found in some Tantric texts). "Self-sacrifice" means an intention to sacrifice oneself. I will discuss several forms of compassionate violence in detail on another occasion.

33 Upāyakauśalya, Tib. D 261, 303v7.

34 Upāyakauśalya, Tib. D 261, 303v5-305v3. For translation, see (Tatz 2016, pp. 73-74). Tatz (Tatz 2016, p. 1) says that its date of compilation is the first century BCE. For analyses of the discourse of compassionate and self-sacrificial killing in the Upāyakauśalya see, Fujita (1995, p. 145), Harvey (2000, pp. 135-36), Gethin (2004, pp. 188-89) and (Gethin 2007, p. 70), Jenkins (Jenkins 2010), Okano (2010), and Jenkins (2016, p. 145). Gray (2007) deals with an extended version of the narrative in a different Tibetan translation (Tib. D 82, 60r1-61v2) of the Upāyakauśalya. As for this version, see Tatz (Tatz 2016, pp. 73-74) (translation), Harvey (2000, p. 136), and Okano (2010, pp. 152-154).

35 Upāyakauśalya, Tib. D 261, 305v1. This is not an unintentional killing.

36 Upāyakauśalya, Tib. D 261, 305r7-v1. Literally, it is "because of that great compassion and that skill in means."

37 The first seven of the Ten Good Deeds are (1) to not kill, (2) to not steal, (3) to not commit sexual misconduct, (4) to not tell a lie, (5) to not speak malicious words, (6) to not speak harsh words, and (7) to not speak idle talk. (However, if a bodhisattva is a renouncer, he is not allowed to transgress the third precept in any way.) The first three (1-3) are traditionally classified as body actions and the other four (4-7) as speech actions. The text does not mention cases of transgressing the last three of the Ten Good Deeds, namely, (8) to not be covetuous, (9) to not be malicious, and (10) to not have wrong views, which are traditionally classified as mental actions (Bodhisattvabhümi, Śĩlapatala, Skt ed. (Dutt 1978), p. 113, 1. 18-p. 115, 1. 20). Thus, there are cases in which a bodhisattva can act contrary to the good deeds regarding body and speech if his state of mind is neither covetuous, malicious, or delusional.

However, in terms of the doctrine of three poisons (viz., desire, hatred, and delusion), Asanga also teaches this: Sins (āpatti) mostly come from hatred (dveșa), not from desire ( $r \bar{a} g a$, indicating affection or compassion for sentient beings [sattvapreman] in particular). He further says that a bodhisattva can do what is forbidden to do as long as he does it out of compassion for sentient beings (Bodhisattvabhūmi, Śilapațala, Skt ed. (Dutt 1978). This also explains in part why a bodhisattva's compassionate and self-sacrificial killing is possible. See also Jenkins 2010, p. 68) and Jenkins (2011, p. 310).

It should also be noted that Asanga presents a different view in his different work. In his Mahāyānasamgraha (Tib ed. (Nagao 1987), Asanga explains as the peculiarity of the profoundness (zab pa nyid kyi khyad par) of the bodhisattva's precepts that if a bodhisattva transgresses any of the Ten Good Deeds (not confined to seven of the ten) with skill in means, it is not sinful, rather quite meritorious, and he attains clear enlightenment soon. 
against killing has been transgressed with skill in means, Asanga analyzes the structure of a narrative, which seems to be some version of the narrative of Captain Greatly Compassionate described above, as follows in the next paragraph. ${ }^{38}$ The bold text respresents the core elements of Asanga's theory of compassionate and self-sacrificial killing: the last two elements, "not sinful" and "much merit," are effects of that killing, and the others are the conditions required for a bodhisattva to carry out that killing successfully.

Now, $\mathrm{X}$ (a robber) is about to kill Ys (many living beings as well as those who are of high moral quality such as the bodhisattva merchants) for the sake of his desire for a small thing (the merchants' wealth). This is regarded as equal to one of the annantarya ("immediate [retribution]"), the gravest sins (viz., patricide, matricide, killing Arhats, injuring the Buddha and causing him to bleed, and splitting the Sangha), ${ }^{39}$ the immediate retribution for which is rebirth in hell. In other words, $\mathbf{X}$ is about to commit ānantarya. If $\mathrm{X}$ kills $\mathrm{Ys}$, then $\mathrm{X}$ will be reborn in hell as karmic retribution for having done so. A bodhisattva (who seems to be Captain Greatly Compassionate) knows this and upon reflection reasons that if he kills $X$, he can save $X$ from being reborn in hell and Ys from being killed. He is convinced that there is no other way to save them than this (last resort), is determined to suffer the bad karmic retribution (rebirth in hell) that his killing $X$ causes him (self-sacrifice), and ascertains that his state of mind is good or neutral (kuśalacitto 'vyākrtacitto $v \bar{a})(1) .{ }^{40}$ Then, being reluctant [in doing so] (rtìyamānah) (2), he kills X purely out of compassion for both X and Ys. In doing so, he is not sinful (anāpattika); indeed, much merit (bahu punyam) is brought to him and others. He has undertaken the act with skill in the means [of doing so] (upāyakauśalya), as explained.

In the Upāyakauśalya and Bodhisattvabhūmi, a bodhisattva makes a decision and intentionally kills the target. However, if the intention of killing is compassionate and self-sacrificial, and if the killing is the last resort to save the target and others from the gravest sin and from hell, then it is not sinful but meritorious. The two processes of reflection delineated in the Bodhisattvabhümi marked as (1) and (2) (viz., to ascertain that his state of mind is good or neutral, and to be reluctant in killing), which are not described in the Upāyakauśalya, help a bodhisattva killer to retain the state of mind that is appropriate for fulfilling compassionate and self-sacrificial killing.

Was that theory of compassionate and self-sacrificial killing used as a soteriology for warriors? Were the required conditions represented in that theory too strict to fulfill for warriors engaged in actual warfare? The two scriptures do not give a clear prescription regarding who

38 Bodhisattvabhūmi, Śīlapațala, Skt ed. (Dutt 1978), p. 113, 1. 18-p. 114, 1. 2: asti kimcit prakrtisāvoadyam api [yad] bodhisattvas tadrūpenopāyakauśalyena samudācarati yenānāpattikaś ca bhavati bahu ca punyam prasūyate / yathāpi tad bodhisattvaś cauram taskarạ̣ prabhūtānām prāniśatānām mahātmanām śrāvakapratyekabuddhabodhisattvānām vadhāyodyatam āmișakimcitkahetọ

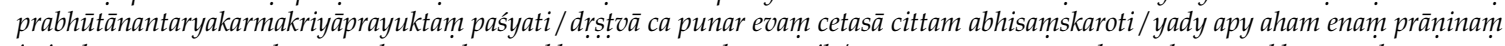
jīvitād vyaparopya narakeșūpapadyeyam kāmam bhavatu me narakopapattih/eșa ca sattva ānantaryakarma krtvā mā bhūn narakaparāyaña

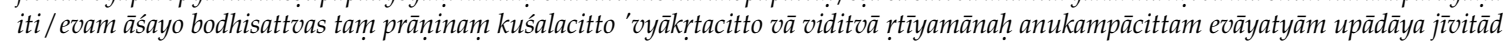
vyaparopayati / anāpattiko bhavati bahu ca punyam prasūyate / "Even if [the act] is one reprehensible by nature, the bodhisattva performs [that act] with such skill in means that he does not become sinful and much merit is brough forth. Accordingly, the bodhisattva sees a robber or thief engaged in committing many acts of anantarya, being about to kill many hundreds of living beings as well as noble ones - śrāvakas ("ones listening to [the preach]"), pratyekabuddhas ("individually awakened ones"), and bodhisattvas - for the sake of a few things for enjoyment. Seeing it, he formed this thought in mind: "Even if I should be reborn in hells after having taken the life of this living being, I wish I be reborn in hells; this sentient being, having committed a nantarya, should not go straight to hell. With such an intention the bodhisattva ascertains that [his thought] is a virtuous thought or a neutral thought and then, being reluctant [in taking life], with only a thought of compassion for the future, he takes the life of that living being. He is not sinful; rather, much merit is brought forth."). This translation is from Tatz (1986, pp. 70-71) with some minor changes. See also Tatz (Tatz 2016, p. 16), Fujita (1995, pp. 148-49), (Schmithausen 1999 , p. 59, footnotes 66 and 67)), Harvey (2000, pp. 136-37), Fujita (2000, pp. 110-11), and Jenkins (2010, p. 69).

39 Killing those who are of high moral quality, such as bodhisattvas, is likely equated with the killing of Arhats. As for various versions of the five ānantarya sins and offenses that are equated with them, see Silk (2007).

40 In his analysis of this discourse in the Bodhisattvabhümi, Jenkins (2011, p. 302) points out the following: The division between good, neutral, and bad states of mind refers to a common abhidharmic classification that distinguishes between good, neutral and bad states of mind. Only the bad states of mind are affected by the mental defilements, viz., desire, hatred, and delusion (which are the three poisons), and so have negative karmic outcomes. 
among the bodhisattvas (such as kings) were permitted to carry this out. ${ }^{41}$ The early Vajrayāna Mahāvairocanābhisaṃbodhivikurvitādhișthānasūtra (abbreviated to Mahāvairocana, "Great Vairocana," seventh century $\mathrm{CE}$ ), which concisely summarizes the theory of compassionate and self-sacrificial killing taught in the Bodhisattvabhumi (but omitting the two processes of reflection previously marked as (1) and (2)), ${ }^{42}$ counts a king as among the practitioners who are permitted to practice it. ${ }^{43}$ However, the Mahāvairocana does not relate in which situations (such as battle) a king may practice it. Examples of the use of elements of the theory of compassionate and self-sacrificial killing can be found in theorizing a non-sinful and meritorious form of warfare in the Satyakaparivarta, which is discussed below.

\section{A Discourse on Warfare in the Satyakaparivarta}

Chapter 6 of the Satyakaparivarta expounds upon a king's ethics of rule from a Buddhist perspective. ${ }^{44}$ It contains a discourse related to warfare. This chapter states that there are four classes of king: wheel-turners ('khor los sgyur ba rnams), great kings (rgyal po chen po rnams), regional kings (khams kyi rgyal po rnams), and vassal kings (rgyal phran rnams). The first class of king, wheel-turner, also called "righteous dharma king" (chos dang ldan pa chos kyi rgyal po), corresponds to the wheel-turner in the Cakkavattisihanāda and the wheel-turner with a golden wheel in the Abhidharmakośa discussed in Section 2 above, who rules moral people in the golden age of dharma. ${ }^{45}$ The other three classes of king are kings in the actual world (ancient India), where people were not morally perfect and armed conflicts frequently occurred. Great kings govern regional kings and vassal kings. The king's ethics of rule are presented to the kings in the actual world. A king who rules according to these ethics is called a "righteous king" (chos dang ldan pa'i rgyal po). ${ }^{46}$ The text teaches the following.

41 Tatz (Tatz 2016, p. 16) points out that some commentators on the Upâyakauśalya limit the permission to perform compassionate and self-sacrificial killing only to bodhisattvas of a higher stage, for whom the "skill in means" is an advanced attainment.

42 Mahāvairocana, Chapter 18, Tib. D 494, 218v6-219r1: de la byang chub sems dpas ched du bsams te srog gcod pa las slar ldog par bya'o // dbyug pa spong zhing 'khon du 'dzin pa spang bar bya'o // des bdag la ci lta ba bzhin du gzhan gyi srog kyang bsrung bar bya'o // gzhan du na gang zag de lta bu dang dngos po de lta bu la bdag gis sdig pa khas blangs la / las de bya ba ni ma gtogs te / de yang 'khon $d u$ 'dzin pa med cing snying rjer gyur pa'i yid kyis bya'o // ("In this regard, a bodhisattva should renounce taking a life with the intention [to do so]. He should abandon a stick [or punishment] and be released from enmity (or hatred). He should also protect others' lives just as [he protects] himself. As an exception, [a case] is excluded [in which] he himself accepts a sin for such person and such matter and carries out that deed: He should carry out that without enmity (or hatered) and with a compassionate mind."). As for the textual relation between the Bodhisattvabhūmi and the Mahāvairocana, see Fujita (1998). The Mahāvairocana also teaches this in the same context as in the Bodhisattvabhūmi (Mahāvairocana, Chapter 18, Tib. D 494, 218v6-220r5).

43 Mahāvairocana, Chapter 18, Tib. D 494, 220r6-r7 (byang chub sems dpa' rgyal srid kyi dbang phyug dang khyi ma dang chung ma dang ... yongs su bskor cing ... ; "a bodhisattva is surrounded by the [work of] governance of the kingdom, household, [his] wife, ..." ") and 220v2 (de la byang chub sems dpa' khyim pa ni / khyim na gnas shing bslab pa'i gzhi lnga gzung ste / thabs dang tshul sna tshogs kyis royal srid la dbang byed do /; "In this regard, a lay bodhisattva lives in [his] residence, observes the Five Precepts, and rules the kingdom with various means and ways."), which appear in the passage explaining bodhisattvas observing the Ten Good Deeds.

44 Satyakaparivarta, Tib. D 146, 101v4-111v7/ S 246, 57.7-85.5/ J 73-101. The title of Chapter 6 is royal po'i tshul ("royal ethics"). Its Chapters 5 (entitled rgyal po'i drung du phyin pa or "Coming to the king") and 8 (entitled yon tan dang skyon bstan pa or "instruction of virtues and flaws") also provide related teachings. In this paper I have also mentioned some teachings in Chapter 5.

45 Satyakaparivarta, Tib. D 146, 102v4-104r2/ S 246, 60.5-64.3 / J 75.9-79.14. For example, Tib. D 146, 102v6-v7/ S 246, 61.2-3/ J 76.4-6: des sa chen po ma lus pa gnod par sdo ba ma mchis shing 'tshe ba ma mchis la / chad pa *ma mchis (mchis J) shing mtshon gyis bda' ba ma mchis pa 'di nyid chos dang *'thun par (mthun par J) snyoms pas legs par phab ste/gnas lags so // (whose Sanskrit can be restored from the Mahāvyutpatti, 3636 (Silk 2013, p. 166))—sa imām eva samudraparyantām mahāpṛthivīm akhilām akanțakām anutpātām adạdenāśastrena dharmeṇa samenābhinirjityādhyāvasati / ("He resides on this just, great ground, entirely to the boundary with the ocean, thornless and calamity-free, after having conquered [it] equally by the dharma and not by punishment or weaponry.") and Tib. D 146, 103v7-104r1/ S 246, 63.6-64.2/ J 79.8-11: 'khor los sgyur ba'i rgyal pos skye dgu skyong ba de'i tshe na chos ma lags pa'i 'dod pa la dga' ba la chags pa 'am / mi rigs pa'i 'dod chen gyis zil gyis non pa'am / log pa'i chos kyis 'khor ba de lta bu'i sems can ma mchis te / "In that age when a wheel-turning king protects the people, there is no such sentient being who is attached to the joy of evil desire, who has given in to [one's own] inappropriate and strong desire, or who is confused by some wrong dharma.").

46 A righteous king in the actual world is distinguished from the "righteous dharma king," a wheel-turner. He is never called "wheel-turner." However, in some passages an ideal king in the actual world is also called "righteous dharma king" or "king" modified by the words "righteous" (chos dang ldan pa) and "dharma" (chos kyi) in some way (D 146, 104v6, 109r6-r7, 109v6, $109 \mathrm{v} 7$, and $111 \mathrm{v} 2 / \mathrm{S} 246,66.4,79.1,80.3,80.4$, and 84.6). If this is not simply a confusion or interpolation that occurred 
A king protects the people and other sentient beings (deities and beasts) in conformity with the Ten Good Deeds. ${ }^{47}$ The Ten Good Deeds constitute an important aspect of the dharma. The text reiterates that the effect of observing the Ten Good Deeds is to attain rebirth in heaven (mtho ris or the like). ${ }^{48}$ A king also relies on treatises (bstan bcos) that include teachings to overcome the "three poisons," or three unwholesome states of mind, namely, desire (chags pa), hatred (zhe sdang), and delusion $(g t i m u g)$. To not have the three poisons is the psychological foundation for fulfilling the Ten Good Deeds. ${ }^{49}$ In order to overcome the three poisons, a king must be heedful and compassionate: Heedfulness (bag mchis pa or bag yod) and compassion (snying rje) are the fundamentally important factors undergirding the king's righteous rule by the Ten Good Deeds. ${ }^{50}$ Heedfulness means to be mindful that his wealth and he himself are impermanent and faulty by nature and to wish to renounce attachment to them. ${ }^{51}$ Compassion is based on heedfulness and, hence, is dispassionate. Compassion takes the form of implementing appropriate measures to "protect the people" (skye dgu rnams kyi skyabs bgyid pa) using his wealth and power to, for example, help his people when any "foreign troops" (pha rol gyi dmag tshogs) harm them, to give foods and other property to those in need, or to punish

during the course of transmission, it may be expressive of the authors' implicit message that an ideal king should imitate a wheel-turner as much as possible.

47 Satyakaparivarta, Tib. Chapter 5, D 146, 99v4-100v6 and 101r2-v3/ S 246, 52.5-55.5 and 56.2-57.5/ J 65.2-68.12 and 69.4-72.4 and, Chapter 6, D 146, 103r1-r2/ S 246, 61.4-5/ J 76.11-16. For the protection of these sentient beings, a king does not destroy their life environment. The text states this (summarized: Satyakaparivarta, Tib. Chapter 6, D 146, 107r4-v4/ S 246, 73.1-74.3/ J 88.8-89.10): A king should not destroy villages, towns, ponds, houses, fruitful trees, crops, or any other things that have been well built because they are common life resources (thun mong gi nye bar 'tsho ba) used by the king and the other sentient beings (sems can gzhan dag), who have not committed any fault (nongs pa ma bgyis pa); because the houses, temples, stūpas, fruitful trees, and the others are inhabited by respective deities (so so' $i$ lha) and sorrow occurs (mi dga' bar 'gyur) if they are destroyed; and because they are also inhabited by various beasts (dud 'gro'i skye gnas su gtogs pa'i srog chags sna tshogs dag, literally "various living beings belonging to the birth of beast"), who have not committed any fault. The king also protects the deities who live in his territory (rgyal po'i khams na lha gang dag gnas pa de dag) by making the bali offering (gtor ma) or offering of particular crops to them.

48 The text is often obscure which heaven it indicates. Satyakaparivarta, Tib. Chapter 5, D 146, 101r5-v3/ S 246, 56.5- 57.5/ J 70.5-71.16 (dbang po'i gnas or "Indra's place," mtho ris or "heaven," dbang phyug 'jig rten or "Indra's world," and lha yi gzhal med khang or "divine palace" for heaven), and Chapter 6, D 146, 111v6-v7/ S 246, 85.3-5/ J 101.9-16 (lha yi rgyal srid or "divine kingdom" for heaven).

49 Satyakaparivarta, Chapter 6, D 146, 104r6-r7/ S 246, 65.1-3/ J 80.9-13: smras pa / bram ze / bstan bcos gang la chos dang ldan pa'i rgyal pos brten cing skye dgu skyong bar *byed pa de (byed pa'i DJ) bstan bcos gang yin / smras pa / rgyal po chen po / de ni bstan bcos gang las mi rigs pa'i chags pa dang / mi rigs pa'i zhe sdang dang / mi rigs pa'i gti mug gi gnyen po rang bzhin nam / rab tu dbye ba'am / phan yon gyi sgo nas bstan pa *ste (te S) / "[Candapradyota] said-O brahmin! Which is the treatise that a righteous king relies on to protect the people? [Satyaka] said-O great king! It is such a treatise that teaches an antidote against evil desire, evil hatred, and evil delusion in terms of the inherent nature, classification, or benefit."). Although it is not stated explicitly in the Satyakaparivarta, this seems to be derived from the traditional Buddhist idea that the three poisons (lobha or desire, dosa or hatred, and moha or delusion) are roots $(m \bar{u} l a)$ of the Ten Bad Deeds and to not have the three poisons is the root of the Ten Good Deeds, found in the Sammāditțhisutta ("Right View Scripture," P ed. (Trenckner 1993), Majjhimanikāya 9, pp. 1. 3-1. 20).

50 Satyakaparivarta, Tib. Chapter 6, D 146, 104r7-v1/ S 246, 65.3-4/ J 80.13-16: de la /gnyin po'i rang bzhin ni 'di lags te/'di lta ste/ de'i gnyen por 'gyur ba ma chags pa dge ba'i rtsa ba dang/zhe sdang ma *mchis pa'i (mchis pa J) dge ba'i rtsa ba dang /gti mug ma *mchis pa'i (mchis pa J) dge ba'i rtsa ba lags so // de la gnyen po kun nas slong ba ni 'di lags te /'di lta ste / bag mchis pa dang snying rje lags so // ("In this regard, to have the nature of antidote [measn] this: Antidotes against those [three poisons] are to not be greedy, [which is] a root of virtue, to not be hateful, a root of virtue, and to not be delusional, a root of virtue. In this regard, what bring [these] antidotes are these: heedfulness and compassion.") and D 146, 104v5/ S 246, 66.2-3/ J 81.7-9: rgyal po chen po chos gnyis po de dag dang ldan na chos dang ldan pa'i rgyal po skye dgu yang dag par skyong bar bgyid *ces bgyi ba (cas bgyi ba D; ces pa S) lags te / bag mchis pa dang snying rje gnyis lags so // ("O great king! It is taught that if being complete with these two virtues, a righteous king protects the people correctly: heedfulness and compassion, [these] two.").

51 Satyakaparivarta, Tib. Chapter 6, D 146, 104v1-v3/ S 246, 65.5-6/ J 80.17-20: rgyal po chen po de la chos dang ldan pa'i rgyal po'i longs spyod rnams dang bdag nyid kyang mi rtag par rtogs shing dran pa nye bar *bzhag (gzhag D) ste / nyes dmigs su lta zhing nges par 'byung ba 'tshal bas longs spyod rnams la spyod cing rgyal po'i dbang phyug gi dbang bgyid pa 'di ni de'i bag mchis pa lags so // ("O Great King! In this regard, a righteous king understands and is mindful that [his] wealth and he himself are impermanent. Seeing them as flaws, [he] wishes to renounce [them]. By [this he] uses [his] wealth and exerts royal power. This is his heedfulness."). Heedfulness (or diligence, appamāda in Pāli) was originally an important concept in Pāli scriptures. The Pāli discourse entitled Appamāda (the first of the discourses having the same title, P ed. (Feer 1960), Samyuttanikāya, Sagāthavagga, 3.2.7, pp. 86-87) tells that appamāda brings both benefits pertaining to present and future lives. See Bodhi (2000a, pp. 179-80) for translation. The Satyakaparivarta also says that "those who are heedful will be reborn in heaven" in the next life (Satyakaparivarta, Tib. Chapter 5, D 146, 101r2-r3/ S 246, 56.2-3/ J 69.7: bag mchis gang lags de ni mtho ris mchi //). 
criminals moderately. ${ }^{52}$ To do all of the above correctly, a king occasionally seeks advice from learned Brahmins and Buddhist renouncers about what is right. ${ }^{53}$

In the discourse related to warfare, a king's compassion is primarily directed toward his people (his subject) and therefore takes the form of implementing measures to protect his people as mentioned above. No word for "compassion" is explicitly used to describe a king's feeling toward opponents who have been armed to fight against him. Nevertheless, it is possible to interpret that a king has some form of compassion for armed opponents. The text says this (summarized): A king should consider that something has caused the opponents to engage in the faulty act of hostility. He should therefore strive to remove that cause and form friendships with them. ${ }^{54}$ However, while the text always portrays a king's compassion for his people as constantly present, its portrayal of his compassionate attitude toward armed opponents is obscured in a particular situation during a time of war as mentioned below. The discourse related to warfare is as follows.

If an enemy army from a foreign country is approaching for battle, then the first thing a king should do is to avoid a war. He should implement the three diplomatic policies separately or in combination to make the enemy army abandon fighting, i.e., forming friendships with it, giving gifts or assistance to it, or intimidating it with allied countries. ${ }^{55}$ The first strategy, forming friendships with the enemy, seems to be most recommended among the three, as mentioned earlier. However,

52 The term skye dgu rnams, which also mean all sentient beings, seems to particularly indicate the king's people in this context. Satyakaparivarta, Tib. Chapter 6, D 146, 104v1-v5/ S 246, 65.6- 66.2/ J 81.1-7: gang la gnas te / ma thob pa'i longs spyod kyi 'bras bu la nye bar mi 'tsho ba dang / *thob pa la'ang (thob pa'ang S) dus ma yin par nye bar mi 'tsho ba dang / dus la bab kyang dbul po rnams la gnod pa bgyis shing *nye bar mi 'tsho ba (mi 'tsho ba J) dang / mu ge'i gnod pa zhig byung na skye dgu rnams kyi skyabs bgyid pa dang / chom rkun gyi gnod pa dang / pha rol gyi dmag tshogs kyi gnod pa dang / gcig la gcig gnod par gyur pa zhig byung na / yang dag par phan 'dogs par bgyid pa dang / dbul po rnams la nor sbyin pa dang / mi srun pa rnams la yang dag par chad pas bcad pa 'di ni / de' $i$ snying rje zhes byyi ste / "Being in that [state of heedfulness], [he does] not use fruits of wealth not acquired [viz., fruits of others' wealth]; [he does] not use [them] in an inappropriate occasion even [the wealth he has] acquired; [he does] not use [them] while harming the poor even if the occasion is appropriate; [he] protects the people [by giving foods] when the harm of famine occurs; [he] helps [the people] correctly when the harm of robbers, the harm of foreign army troops, and anything harmful to each other occurs; [he] gives property to the poor; and [he] punishes criminals correctly. These are proclaimed to be his compassion."). See also Zimmermann (2000, pp. 189-91).

53 Satyakaparivarta, Tib. Chapter 6, D 146, 107r2-r3/ S 246, 72.5-7/ J 88.1-4: rgyal po chen po / chos dang ldan pa'i royal pos ni rang gi ris na ya rabs su btu ba'i dge sbyong dang bram ze mkhas pa gsal ba rig pa dang ldan pa de dag gi drung du mchi zhing dus dus su /dge ba ni gang / mi dge ba ni gang / ci byas na legs par 'gyur / ci byas na sdig par *mi 'gyur ('gyur J) zhes dri bar bgyi zhing de dag chos ston par 'gyur ba'i skabs dbye bar bgyi'o // ("O Great king! A righteous king should sometimes visit those ascetics and brahmins, [who are] to be gathered as virtuous men in his territory (ris), [who are] learned, and [who] have clear knowledge, and ask [them] 'What is good? What is bad? What is good to do? What is a deed [that is] not sinful?' [He] should provide an occasion for them to preach dharma.") See also Zimmermann (2000, pp. 185-86).

54 Satyakaparivarta, Tib. Chapter 6, D 146, 110v6 and 111r3/ S 246, 82.7 and 83.4-5/ J 98.11 and 99.7-8: dgra rnams la de'i rgyus nyes $p a^{\prime} i$ 'du shes dang ... dgra rnams la de'i rgyus nyes pa'i 'du shes kyis gnas pa ni / de'i rgyu yongs su spong zhing / skye bo gzhan lta ci smos kyi / dgra rnams dang yang mdza' bar bgyid pa'o // ("[A king should have] a thought that opponents have a reason for committing the fault [of hostility], and ... Abiding on the 'thought that opponents have a reason for committing the fault' [means that] he removes that cause (reason), and he also forms friendships with the opponents; let alone others.")

55 Satyakaparivarta, Tib. Chapter 6, D 146, 109v6-110r3/ S 246, 80.4-81.1/ J 96.7-18: smras pa / bram ze royal po'i chos de ltar yongs su rdzogs pa dang ldan pa'i chos kyi rgyal pos *'thab mo'i (thab mo D) g-yul zhig nye bar gnas na ji ltar nan tan du bya/smras pa/rgyal po chen po dus gsum du thabs la mkhas pa'i rnam pa gsum gyis nan tan du bgyi'o // de la dus gsum ni thog ma'i dus dang / bar gyi dus dang / tha ma'i dus so // de la thog ma'i dus kyi thabs mkhas pa ni/gal te rgyal po'am blon po mdza' bar bgyi bas 'grub par gda' na/yang mdza' bar bgyi bas nye bar bzung ste *' thab mo (thab mo D) de zhi bar bgyi'o// gal te phan gdags pa zhig gis 'grub par gda' na yang phan *gdags pas (gdags pa J) nye bar bzung ste *'thab mo (thab mo D) de zhi bar bgyi'o// gal te phyogs mang po yongs su bzung ba dang de bas lhag pa'i dgrar 'gyur ba'i 'jigs pa la sogs pa bstan pas 'grub par gda' na yang / de gnyis bstan pas nye bar bzung ste *'thab mo (thab mo D) de zhi bar bgyi ste / de ltar dus dang po la thabs mkhas pa sbyar bar bgyi'o // gal te de dag mdza' bar bgyi ba dang / phan gdags pa dang /'jigs pa bstan pa ... ("[King Candapradyota] said-O Brahmin! How should a dharma king, [who] has thus perfectly fulflled the king's dharma, do earnestly if [the enemy] army for battle is arrayed near [him]. [Satyaka] said - O Great king! [He] should cope [with it] earnestly by three ways of skill in means at three times. In this regard, the three times [mean] the times of the first, midst, and last (viz., the first, second, and third steps). Of them, the skill in means at the time of the first [means this]: If a king or minister is able to achieve [avoiding a war] by forming friendship [with the enemy], [he] should pacify [viz., avoid] the war by means of forming friendship. If [he] is able to achieve [this] by giving gifts [or assistance], [he] should pacify the war by means of giving gifts. If [he] is able to achieve [this] by [his] holding of many directions [viz., alliance with many countries] and by giving [the enemy negative senses] such as a sense of fear of [his] becoming a greater opponent thanks to that [alliance], [he] should pacify the war by means of showing these two [viz., by means of intimidating the enemy with allied countries]. [He] should use the skill in means in this way at the time of the first. If ... these [three policies of] forming friendship [with the enemy], giving gifts [to the enemy], and intimidating [the enemy] ... "). 
if all of these strategies are unsuccessful, then the king should engage in war as a last resort, with three thoughts in mind: that he completely protects his people, that he defeats the enemy, and that he captures the enemy warriors alive ${ }^{56}$ He is required to try to win the war without killing the enemy. Subsequently, he deploys his fourfold army. ${ }^{57}$ All of the king's actions mentioned above, namely the three diplomatic policies to avoid a war, warfare as a last resort with the three thoughts in mind, and military deployment are his "skill in means" (thabs la mkhas pa or thabs mkhas pa). ${ }^{58}$

However, it does not seem to be always easy to capture alive the enemy warriors, who rush at him with weapons in hands. What happens to him if he has wounded or killed the enemy in battle? The text runs as follows:

Even if the king, [who] is skillful in means and [who] has a thorough knowledge of warfare, kills or wounds the [warriors of the] foreign army, by that, for the king, there is little fault (kha na ma tho ba chung), there is little vice (bsod nams ma lags pa chung ba), and receiving the [karmic] consequence [of it] also becomes uncertain ('bras bu myong ba yang nges pa ma mchis par 'gyur). Why is this? [It is] because in this way he has performed that task with compassion and never abandoning in mind. As he has performed that task by completely abandoning himself and [his] wealth for the sake of thorough protection of the people and [for the sake of his] son, wife, and clan, immeasurable merit (bsod nams tshad ma mchis pa) will also grow. ${ }^{59}$

The term "skillful in means" in the above passage seems to indicate not only the king's actions in the three diplomatic policies, warfare as a last resort, and military deployment but also killing the enemy in battle. The king will not suffer the bad karmic result for killing or wounding because he has done it with compassion and never abandoning in mind. There is immeasurable merit because he has done this while completely abandoning himself and his wealth to protect his people and for the sake of his son, wife, and clan. As Jenkins pointed out ${ }^{60}$ this passage explaining the fighting king's

56 The idea that a king wins a battle by capturing the enemy alive (jī̄ogāaha in Pali, jūvagrāha in Sanskrit, srog gzung ba in Tibetan, "capturing alive"), which is used in a positive sense, can also be found in the Alinacittajätaka (abbreviated to Alīnacitta) and the Bhojānīyajātaka (abbreviated to Bhojānīya). According to the Alīnacitta, Prince Alinacitta (the Buddha in a former life) won the war against the king of Kosala with the help of his military elephant, which captured the king alive, warned him, and let him go (Alīnacitta [Pāli Jātaka 156], P ed. (Fausboll 1990), p.22, 1. 10-1. 15). The Bhojānīya is a story of a military horse (another former life of the Buddha) that defeated the troops of seven enemy kings by capturing the kings alive, making them vow not to be antagonists, and sending them back to their countries (Bhojānīya [Pāli Jātaka 23], P ed. (Fausboll 1990), pp. 178-80, especially p. 180, 1. 9-1. 15 and 1. 20-1. 23).

57 Satyakaparivarta, Tib. Chapter 6, D 146, 110r3-v2/ S 246, 81.1-82.1/ J 96.18-97.14: gal te de dag mdza' bar bgyi ba dang / phan gdags pa dang / 'jigs pa bstan pa *gang gis (gang gi J) kyang bsgo ste ma btub na chos dang ldan pa'i rgyal pos sems gsum nye bar *bzhag (gzhag D) ste *'thab mo (thab mo D) bgyi'o // gsum gang zhe na /... dang por skye dgu yongs su bskyang ba la sems nye bar gzhag par bgyi'o // gnyis pa ni phas kyi dgra las rgyal bar bgyi ba'i sems so // gsum pa ni srog gzung ba'i sems te / sems gsum po 'di dag nye bar *bzhag (gzhag D) la/dpung gi tshogs yan lag *bzhi pa (bzhi po J) la bka' stsal bar bgyi ste / de ltar dus bar ma la thabs mkhas pa sbyar bar bgyi'o // dus tha ma la ni dpung gi tshogs yan lag bzhi pa de dag dpa' ba tha ma dang / dpa' ba 'bring dang / dpa' ba rab kyi tshul du g-yul bsham par bgyi'o //... de ltar tha ma'i dus la thabs mkhas pa sbyar bar bya'o // ("If [he] is not successful after having commanded even by [all of] these [three policies of] forming friendship, giving gifts, and intimidating, the righteous king can (or should) wage a war with three thoughts in mind. [King Candapradyota questioned -] What are [those] three? ... [Satyaka said -] First, [he] should resolve to protect the people completely. The second is the mind to defeat the enemy. The third is the mind to capture [the enemy warriors] alive. With these three thoughts in mind [he] should command [his] fourfold army. [He] should use the skill in means in this way at the intermediate time. At the final time [he] should arrange the troops of the fourfold army in the way of [dividing it into] inferior warriors, middle-level warriors, and superior warriors. ... [How to arrange them is explained.] ... [He] should use the skill in means in this way at the final time."). See also Zimmermann (2000, pp. 201-2). As for the translation of the srog gzung ba (*jīvagrāham) as "to capture alive," see Zimmermann (2000, p. 202, footnote 73) and Jenkins (2010, p. 67).

58 See footnotes 55 and 57 above.

59 Satyakaparivarta, Tib. Chapter 6, D 146, 110v2-v4/ S 246, 82.1-4 / J 97.15-98.2: de ltar thabs mkhas shing g-yul legs par shes pa'i ${ }^{*}$ rgyal pos (rgyal po J) ni pha rol gyi dpung *bkum mam (ngam S) / rma byung yang / des royal po la kha na ma tho ba chung zhing bsod nams ma lags pa chung ba dang / 'bras bu myong ba yang nges pa ma *mchis par (chis par J) 'gyur ro // de ci'i slad du zhe na /'di ltar des snying rje ba dang / yongs su *mi gtang ba'i (ma btang ba'i J) sems kyis las de mngon par 'du bgyis pa'i slad du'o // gang des skye dgu yongs su bskyang ba dang / bu dang / chung ma dang / rigs kyi don du bdag dang longs spyod yongs su *btang ste (btang ba ste J) las de bgyis pas / gzhi de las *bsod nams (bsod nams kyang J) tshad ma mchis pa yang rab tu 'phel lo //. See also Zimmermann (2000, pp. 201-4) and Jenkins (2011, p. 68).

60 See Section 1 and footnote 9 above. 
innocence and merit-producing power consists of elements derived from the theory of compassionate and self-sacrificial killing (which is also non-sinful and meritorious) examined in Section 3 above. However, there are some important differences between them, which will be discussed in detail below. The meaning of the phrase "never abandoning" (mi gtang ba) is obscure. I consider that it means to not abandon the first two of the three thoughts that the king must have in mind in war, namely, that he completely protect his people and that he defeat the enemy because he has abandoned the final thought that he capture the enemy alive.

Which form of warfare is addressed in this discourse? Previous studies have attempted to descibe it by using the dichotomy of aggression versus defense without elaborating definitions of these two concepts. Schmithausen interprets the Satyakaparivarta as dealing only with a purely defensive war against invaders. ${ }^{61}$ However, Zimmermann argues that the text does not explicitly limit the situation to a purely defensive war. ${ }^{62}$ The abovementioned fourfold diplomatic policy of friendship, gifts, intimidation, and warfare as a last resort, which are defined as the king's skill in means, is, as Zimmermann pointed out, derived from the fourfold diplomatic policy (upāya) of the sāman ("conciliation"), the dāna ("gift"), the bheda ("separation"), and warfare as a last resort found in the Brahmanical books of dharma. ${ }^{63}$ It should also be noted that this fourfold policy is taught to enable military expeditions to conquer foreign countries (viz., for aggressive wars) in the Manusmrti, a representative Brahmanical book of dharma. ${ }^{64}$ (Although he does not kill anyone, a wheel-turner's conquest examined in Section 2 above may also be seen as somewhat aggressive because his wheel rolls from his location to the rival king's territory to start his conquest.) However, the Satyakaparivarta presents only a simple statement regarding how military conflict starts: "if [the enemy] army for battle is arrayed near [to the king]." 65 In addition, the text does not use either "aggressive" or "defensive," which is the fundamental problem in explaining this form of warfare in these terms. The best interpretation seems to be that warfare in the Satyakaparivarta deals with a king's "protection" of his people, which might take the form of either defense or attack, according to the situation. Jenkins says that all prescribed activities of kings for his people are regarded and referred to as "protection" in the Brahmanical books of dharma. ${ }^{66}$ I stress that the dichotomy of aggression and defense is not always a useful framework for understanding Buddhist attitudes about war in ancient India.

As mentioned above, the king's non-sinful and meritorious killing in battle in the Satyakaparivarta translated above has some elements of compassionate and self-sacrificial killing taught in the three scriptures examined in Section 3 above: "bodhisattva," "skill in means," "the last resort," "compassion," "self-sacrifice," "not/little sinful," and "much/immeasurable merit." However, differences can be found between them, which previous studies have not reviewed effectively. We can examine three major differences.

(1) Which Aspects of Himself a Killer Sacrifices and for Whom He Sacrifices Himself:

In the Upāyakauśalya, Bodhisattvabhūmi, and Mahāvairocana, the bodhisattva killer's self-sacrifice refers to suffering rebirth in hell for the sake of both the target and those who are about to be killed by the target. However, in the Satyakaparivarta, the king's self-sacrifice signifies abandoning himself (viz., his life $)^{67}$ and his wealth for the sake of his people, family, and clan members. The text does not state that the king is determined to suffer rebirth in hell or that he sacrifices himself for the opponents whom

61 Schmithausen (1999, p. 54).

2 Zimmermann (2000, pp. 199-200). Jenkins agrees with him.

Zimmermann (2000, pp. 200-1).

Manusmrti, Skt ed. (Olivelle 2005), 7.18-200.

65 The text is 'thab mo'i g-yul zhig nye bar gnas na. See footnote 55 above. See also the Satyakaparivarta, D 110v5/ S 246, 822.4/ J 98.2-3, where the same text also appears.

66 Jenkins (2010, p. 67).

67 Zimmermann (2000, p. 201) interprets abandonment of himself as the abandonment of his life. I agree with him. In his Catuhśatakațīka, Candrakīrti also discusses abandoning oneself (and one's wealth) in battle (g-yul ngor bdag ... gtong ba) as meaning abandoning [one's] life (and wealth) in battle (g-yul ngor srog gtong ba) (Catuhśatakațikā, Chapter 4, Tib. D 3865, 84r6 and 85r3). 
he kills. This is not strange. Being determined to abandon his life and wealth in battle for the sake of his people, family, and clan members is an element of the Brahmanical ethics of the ksatriyas ${ }^{68}$ and seems to be an attitude more common among kings than being determined to suffer rebirth in hell for the sake of his opponents. The authors of the text seem to have changed the meaning of self-sacrifice in order to make it more acceptable for kings. Furthermore, the king's willingness to abandon his life and wealth is also Buddhist: It can be regarded as being psychologically rooted in his heedfulness (indicating the need to be mindful of the impermanence of himself and his wealth). Heedfulness is the essential factor underlying a king's rule from a Buddhist perspective, as explained earlier. Therefore, it brings much merit. Thus, the element of self-sacrifice is modified into a more Brahmanical and realistic one while retaining a Buddhist nature.

(2) Why the Victims are Killed:

In the Upāyakauśalya, Bodhisattvabhūmi, and Mahāvairocana, the bodhisattva killer has compassion for the target. Therefore, he kills the target for the sake of the target himself (i.e., to save him from committing a anantarya, the gravest sin). However, the Satyakaparivarta says that the king kills enemy warriors as a last resort to win the war to protect his people. It does not say explicitly that he kills the opponents for the sake of the opponents themselves. It is also obscure whether the opponents are about to commit annantarya. Instead, the Satyakaparivarta teaches that the death of enemy warriors is ultimately a karmic effect of their intention to harm the king, a righteous one. The text says that "those opponents with a mind of harming him (viz., the king) will be destroyed and cease to exist due to the fault [of theirs that is] each one's karmic maturation." ${ }^{69}$ The king has some form of compassion for the opponents as discussed earlier and tries to capture them alive, but he unavoidably kills them, which is an effect of the enemy warriors' own karma. The logic that explains the plausibility of a king's killing of opponents in battle taught in the Satyakaparivarta is similar to the logic that the Buddha used to explain why the Sākyas, the Buddha's kinsmen, were destroyed by Virūḍhaka's army: unavoidable karmic retribution for their evil deed in the past. ${ }^{70}$ In actual wars, it does not always happen that enemy warriors are about to commit ānantarya such as killing Arhats or those equivalent to Arhats. However, it happens more often that enemy warriors have intentions to harm in battle their opponent king, who is righteous from the Buddhist viewpoint. The authors of the Satyakaparivarta seem to have arranged the theory to be more suitable to actual warfare by shifting the interpretation of the enemy's flaw from committing a nantarya to having an intention to harm a righteous king.

(3) Whose Benifit is the Main Concern:

Chapter 6 of the Satyakaparivarta, the main chapter on royal ethics which deals with the ethics of war I examine here, closes with words saying that such a righteous king who protects his people will be "reborn among gods in heaven, the happy state of existence."71 The Satyakaparivarta states that

68 See footnotes 27 and 73 in this paper.

69 Satyakaparivarta, Tib. Chapter 6, D 146, 111v2/ S 246, 84.5-6/ J 100.3-5: de la gnod par sems pa'i dgra rnams rang rang gi las kyi rnam par smin pa'i nyes pas phung zhing bas pa dang / ma mchis par 'gyur lags so //. Strangely, previous studies have not sufficiently considered this line. This is perhaps because this line appears in the last passage of Chapter 6, which explains the effects that a righteous king acquires and not in the passage that explains the non-sinful and meritorious killing in warfare, which I translated above.

70 Several Buddhist scriptures, such as Zhi Qian's Chinese translation of the Arthapadasütra (Yizujing, third century CE), contain a narrative of the destruction of the Sákyas. Murakami (1996) presents a comparative study of several versions of this narrative preserved in Pāli (such as Buddhaghosa's Dhammapadațthakathā), Chinese, and Sanskrit texts. The Arthapadasūtra or Yizujing (T 198, partially corresponding to the Atțakavagga of the Pāli Suttanipāta) is perhaps the oldest among the extant texts that contain this narrative. See also Schmithausen $(1999$, p. 49).

A similar idea is also found in a discourse related to death punishment in the Milindapañha ("Questions of Milinda," second century BCE-second century CE). The protagonist Buddhist monk Nāgasena says that a king's execution of a robber occurs as a karmic effect of what the robber did in the past (Milindapañha, P ed. (Trenckner 1962, p. 184, 1. 24-p. 186, 1. 24)). See also Rhys Davids (1890, pp. 254-57) and Nakamura and Nakamura and Hayajima (1964, pp. 157-60) for translations. As for the discourse in the Milindapañha, see also Schmithausen (1999, p. 54, footnote 41) and Jenkins (Jenkins 2010, pp. 64-65 and 2016, p. 133 and footnote 14).

71 Satyakaparivarta, Tib. Chapter 6, D 146, 111v2-v3/ S 246, 84.6-7/ J 100.5-8: royal po chen po chos dang ldan pa' $i{ }^{*}$ chos kyi rgyal po (rgyal po J) de ltar skye dgu skyong ba ni 'jig rten na des pa rnams la nongs pa ma *mchis par (mchis pa J) 'gyur lags te / lus zhig nas 
there is "immeasurable merit" through that warfare, but it is not clear whether anything very positive occurs to the opponents who were killed, such as being reborn in heaven as taught in the Upāyakauśalya. In the Satyakaparivarta, as described above, the king neither sacrifices his life and wealth nor kills his opponents for the sake of the opponents themselves. A possibility cannot be ruled out that the killed opponents' happy destination is implied by the words "immeasurable merit." However, whichever the authors' implication might be, what can be safely said is that the authors of this discourse were mainly concerned with how a king should protect his people, ${ }^{72}$ and how he should attain a happy rebirth in heaven. The authors' concern mentioned here is in line with the idea traditional both in Brahmanism and Buddhism since the age of Aśoka, that one of the most important functions of a king is to protect his people. ${ }^{73}$ Such a king, according to the Satyakaparivarta, is reborn in heaven after death, as mentioned earlier.

\section{Conclusions}

The Satyakaparivarta provides ethical instruction to a king to achieve his role of fighting in battle without creating the negative karma that killing generally produces. If a king has killed the enemy in war to protect people as a last resort with a mind of compassion, never abandoning, and self-sacrifice, he is not sinful and is meritorious. This idea of warfare consists of elements derived from the theory of compassionate and self-sacrificial killing, a form of Mahāyānist compassionate violence carried out as a form of skill in means, which is what the Buddha did in his past life according to the Upāyakauśalya and which was presented for a bodhisattva as a case of exception in observing the precept against killing according to Asanga and the Mahāvairocana. However, significant differences can be found between the king's killing in war in the Satyakaparivarta and the theory of compassionate and self-sacrificial killing. In the Satyakaparivarta, combined with ideas external to Buddhism, both the elements of compassion

gum pa'i 'og tu yang bde 'gro mtho ris kyi 'jig rten du lha'i nang du skye bar 'gyur lags so // ("O Great king! the righteous dharma king, [who] protects the people in this way [explained in this whole chapter], is not faulty in [the eyes of] noble ones in the world. After the destruction of [his] body and death [he] is reborn among gods in heaven, the happy state of existence."). The phrase "the righteous dharma king" (chos dang ldan pa'i chos kyi rgyal po) indicates the righteous king in the actual world in this context. If J's reading is accepted, it is "the righteous king."

72 In this way, in the Satyakaparivarta, a king's compassion for his people is always apparent, but his compassion for his opponents becomes obscured in a particular situation. I consider that this is the key to understanding why a righteous king, who may kill or wound opponents in battle, never executes criminals by death or severe forms of physical punishment (viz., destroying the criminal's physical organ and amputation). This question has puzzled modern scholars (see Zimmermann 2000, p. 204). The Satyakaparivarta gives three reasons for the absolute ban of severe punishment: (1) Executing severe forms of punishment including death is a transgression of the precept against killing. (2) A king must be compassionate: He must punish criminals compassionately like a father's punishment of his son to educate or reform him. (3) Criminals suffer unhappy destinations after having been executed by death or severe forms of physical punishment. However, why are these reasons not applied in the same way to absolutely prohibit a king from killing in war? To this question, it is necessary to consider who are criminals. Most criminals whom a king can punish under his rule are evil doers from among his people, not people belonging to foreign kings. On the other hand, opponents whom a king may kill in war are warriors belonging to foreign kings. As discussed in Section 4 above, a king is always compassionate to his people, but his compassion to his opponents is obscure. Therefore, a king never kills criminals (his people) in punishment and may kill foreign opponents in a war to protect his people. There are also cases in which a king must punish enemy warriors whom he captured alive in a war. However, unlike the time of war during which enemy warriors rush at him and his people in attack, there is no urgent need of killing the captured warriors, whose freedom of action is much restricted. A righteous king also has some form of compassion for his opponents. He reforms the captured opponents through moderate punishment compassionately and forms friendships with them. As for details of a view of punishment in the Satyakaparivarta, see Sugiki (2018, pp. 6-8; Sugiki 2020, forthcoming).

73 As known from his inscriptions in the third century BCE, Aśoka's goal was to realize his people's happiness in this life and the next life (the latter of which, the fruit in the next life, was more important to him). He did not mention his own happiness explicitly, but it seems to be implied. Aśoka's rock edict, no. 6 (Sen 1956), p. 79, 1. 13-1. 15 (nāsti hi kammataram

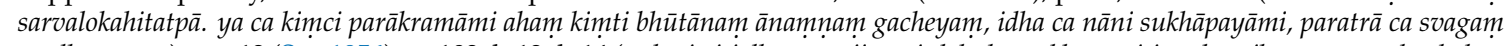
ārādhayamtu.); no. 13 (Sen 1956), p. 103, 1. 13-1. 14 (sā hoti piti dhammavijayași. lahukā cu kho sā piti. pālaṃtikyam eva mahāphalam mạ̣nati devānampiye); and Kalinga rock edict, no. 1 (Sen 195́), p. 109, 1. 7-1. 9 (athā pajāye ichämi hakam kim ti savena hitasukhena hidalokikapālalokikena yūjevū ti, tathā savamunisesu pi ichāmi hakam.). I have used translations by Sen (1956, pp. 78, 102, 108), Tsukamoto (1976, pp. 92, 93, 105, 108), and Dhammika (1993, p. 11, pp. 16-17, and p. 18). For a Buddhist example after Aśoka, see the narratives of wheel-turners examined in Section 2 above. For a Brahmanical example, Manusmrti, Skt ed. (Olivelle 2005), 7.142-144 (kṣatriyasya paro dharmah prajānām eva pālanam / nirdiștaphalabhoktā hi rājā dharmena yujyate //: "For a kṣatriya the highest dharma is certainly the protection of his people because the king, [who] enjoys the indicated rewards, is bound with the dharma."). 
and self-sacrifice are modified into ones that seem to be more realistic and acceptable for kings while retaining a Buddhist nature: In the Satyakaparivarta, a king's compassion for opponents becomes obscure in a particular situation during a time of war; his self-sacrifice means to renounce attachment to his life and wealth for the sake of his people and kinsmen and does not refer to the determination to suffer rebirth in hell for the sake of his opponents; the opponents are killed as a karmic retribution for their intention to harm the righteous king rather than because of their committing a anantarya; and heedfulness (meaning being mindful of impermanence) and compassion, which are principal Buddhist virtues, are the psychological bases for these actions.

Meanwhile, in order to achieve innocence and merit in warfare, a king must be righteous, must firmly observe the dharma, (the framework of which is formed by the Ten Good Deeds), must not have the three poisons (which is the foundation for the Ten Good Deeds), and must have heedfulness and compassion (which are the bases for not having the three poisons). Therefore, the Satyakaparivarta's discourse on warfare is also presented to encourage a king, whose role includes taking others' lives, to be a firm observer of the dharma. A king is also required to have some form of compassion to armed foreign opponents and attempt to form a friendship with them. A righteous king such as this never kills anyone in battle until it becomes unavoidable to protect his people, and even when he does kill, he never does it in such an unwholesome state of mind as hatred.

Buddhist discourse on warfare has multiple aspects. One should not restrict it to its potential application as justification or empowerment for warfare. The discourse in the Satyakaparivarta does not acknowledge all forms of warfare: It sets several conditions on killing in battle. One can interpret these conditions as producing the effect of limiting permissible forms of warfare to a certain degree. However, many of these conditions, such as what the karmic status or moral quality of the king is, to what degree he is mindful of impermanence, whether he is determined to sacrifice his life and wealth, and to what extent he is compassionate, are internal and hence difficult for others to check objectively. In a sense, those conditions were set for an individual king to avoid acquiring the karmic potential that would negatively affect him. It is only after death that he knows whether he did these successfully. The discourse in the Satyakaparivarta should not be entirely equated with the just war theories, which are presented to judge whether a particular war satisfies the conditions required for being just, ${ }^{74}$ or with mere justification or empowerment concerning the use of warfare. However, this does not exclude the possibility that they may be interpreted in this way.

What are the factors, or doctrinal concepts, that constitute the discourse related to warfare in the Satyakaparivarta? They are the social status of a king; the idea that warfare is the last resort; having a mind to protect the people; having a mind to benefit one's family and clan members; conceptions of the dharma, such as the precept against killing; the idea of karma; the moral qualities of participants; being mindful of the impermanence of one's existence and wealth; and states of mind or intentions, such as the mind to sacrifice one's life and wealth, in addition to compassion. These factors, aside from the first three, are not necessarily or exclusively associated with a king's duty including warfare. Originally, most of them are components of discourses on spiritual paths to attain a happy next life or Nirvāna. Thus, the Satyakaparivarta's discourse on tolerating warfare partially comprises the same factors as those constituting peaceful discourse. However, because of those factors, its discourse can be a guide for a king to attain salvation.

The Satyakaparivarta's treatment of enemy warriors, who may be killed in war because of their own karma and whose salvation after death is not explicitly mentioned, may not be fully satisfying for some. Although it mentions a wheel-turner, the Satyakaparivarta does not describe how a moral and peaceful world can be realized in which (a king can become a wheel-turner and) warriors never have such ill

74 Tikhonov (2013, p. 9) also mentions the difference between Buddhist teachings related to warfare and Christian just war theories: "Codifying the concrete rules of 'acceptable warfare' ... tends to be entrusted to the worldly rulers, in the spirit of the Buddhist separation between sacred (monastic) and profane realms." However, he does not discuss in detail the soteriological aspects of those Buddhist teachings. 
intentions as harming the righteous and so are never destroyed. According to the Cakkavattisīhanāada discussed in Section 2 above, such a world is realized after many successive ages of grassroots endeavor: First, each individual reflects on his or her own deeds, then more individuals come to reflect on their deeds, and in the end, the world becomes reflective and acts righteously in accordance with dharma. This sort of instruction is not included in the Satyakaparivarta, because the text's main concern is to teach how a king should protect his people and how he might attain a happy rebirth in heaven while being active during an age of moral depravity.

Funding: This research and the APC were funded by the Grant-in-Aid for Scientific Research (C) (17K02216), Japan Society for the Promotion of Science.

Acknowledgments: I am grateful to Professor Norihisa Baba for having checked my translation of the Pāli texts. I appreciate the helpful advice and suggestions of four peer reviewers.

Conflicts of Interest: The author declares no conflict of interest.

$\begin{array}{ll}\text { Abbreviations } \\ \text { DN } & \text { Dīghanikāya. } \\ \text { MN } & \text { Majjhimanikāya. } \\ \text { P ed. } & \text { Pāli text critically edited } \\ \text { PTS } & \text { Pāli Text Society } \\ \text { Skt ed. } & \text { Sanskrit text critically edited } \\ \text { SN } & \text { Saṃyuttanikāya } \\ \text { T } & \text { Taishō recension of the Chinese Buddhist canon } \\ \text { Tib. D } & \text { Sde dge recension of the Tibetan Buddhist canon } \\ \text { Tib ed. } & \text { Tibetan text critically edited } \\ \text { Tib. S } & \text { Stog Palace recension of the Tibetan Buddhist canon }\end{array}$

\section{Primary Sources}

Appamādasutta (SN, Sagāthavagga, 3.2.7). P ed. (Feer 1960) (PTS, SN vol. I), pp. 86-87. Abhidharmakośakārikā (and -bhāṣya) of Vasubandhu. Skt ed. (Pradhan 1967).

Alīnacittajātaka (Pāli Jātaka 156). P ed. (Fausboll 1990) (PTS, Jātaka vol. II), pp. 17-23.

Aśokāvadāna. Skt ed. (Mukhopadhyaya 1963).

Upāyakauśailyasūtra. Tib. D 261.

Cakkavattisīhanādasuttanta (DN 26). P ed. (Carpenter 1947) (PTS, DN vol. III), pp. 58-79.

Catuhśatakațīkā of Candrakīrti. Tib. D 3865.

Bodhisattvabhūmi of Asanga. Skt ed. (Dutt 1978).

Bhojānīyajātaka (Pāli Jātaka 23). P ed. (Fausboll 1990) (PTS, Jātaka vol. I), pp. 178-80.

Manusmrti. Skt ed. (Olivelle 2005).

Mahābhārata. Skt ed. (BORI edition of the Mahābhārata 1966).

Mahāyānasamgraha. Tib ed. (Nagao 1987).

Mahāvamsa. P ed. (Geiger 1908).

Mahāvairocanābhisaṃbodhivikurvitādhiṣthānasūtra. Tib. D 494.

Mahāsudassanasuttanta (DN 17). P ed. (Rhys Davids and Carpenter 1947) (PTS, DN vol. II), pp. 169-99.

Milindapañha. P ed. (Trenckner 1962).

Yodhājīvasutta (SN, Saḷāyatanavagga, 8 (42).3). P ed. (Feer 1960) (PTS, SN, part IV), 308-9.

Rajjasutta (SN, Sagāthavagga, 4.2.10). P ed. (Feer 1960) (PTS. SN, part I), pp. 116-17.

Satyakaparivarta ('Phags pa byang chub sems dpa'i spyod yul gyi thabs kyi yul la rnam par 'phrul ba bstan pa zhes bya ba theg pa chen po'i mdo). Tib. D 146, S 246 (or Vol. 77, 1), and Tib ed., Jamspal (2010a).

Sammādițthisutta (MN 9). P ed. (Trenckner 1993) (PTS. DN, vol. I), pp. 46-55. 


\section{References}

Bodhi, Bhikkhu. 2000a. The Connected Discourses of the Buddha: A New Translation of the Samyutta Nikāya, vol. I. Boston: Wisdom Publication.

Bodhi, Bhikkhu. 2000b. The Connected Discourses of the Buddha: A New Translation of the Samyutta Nikāya, vol. II. Boston: Wisdom Publication.

BORI edition of the Mahābhārata. 1966. Critical Edition Prepared by Scholars at Bhandarkar Oriental Research Institute BORI Entered by Prof. Tokunaga and then maintained/updated by Prof. John Smith. Available online: https://sanskritdocuments.org/mirrors/mahabharata/mahabharata-bori.html (accessed on 23 November 2019).

Carpenter, J. Estlin. 1947. The Dīgha Nikāya, vol. III. London: Published for the Pali Text Society by Geoffrey Cumberlege, Oxford University Press. First published 1911.

Collins, Steven. 1998. Nirvana and Other Buddhist Felicities. Cambridge: Cambridge University Press.

Dhammika, Ven. S. 1993. The Edicts of King Asoka. Sri Lanka: Buddhist Publication.

Dutt, Nalinaksha. 1978. Bodhisattvabhūmih: Being the XVth Section of Asangapāda's Yogācārabhūmih, 2nd ed. Patna: K. P. Jayaswal Research Institute. First published 1966.

Fausboll, V. 1990. The Jātaka Together with Its Commentary Being Tales of the Anterior Births of Gotama Buddha, vol. I. Oxford: Pali Text Society. First published 1877.

Fausboll, V. 1990. The Jätaka Together with Its Commentary Being Tales of the Anterior Births of Gotama Buddha, vol. II. Oxford: Pali Text Society. First published 1879.

Feer, M. Leon. 1960. Saṃyutta-Nikāya of the Sutta-Pițaka, Part I (Sagātha-vagga). London: Published for the Pali Text Society by Luzac. First published 1884.

Feer, M. Leon. 1960. Saṃyutta-Nikāya of the Sutta-Pitaka, Part IV (Saḷayatana-vagga). London: Published for the Pali Text Society by Luzac. First published 1894.

Fujita, Kōkan. 1995. Bosatsuji Kaibon ni Tokareru Sesshō nitsuite. Mikkyō Bunka 19: 136-52.

Fujita, Kōkan. 1998. Hōben wo Tomonau Jyūzen Kai: Dainichi Kyō to Bosatsuji Kai Bon ni okeru. In Indo Mikkyō no Keisei to Tenkai. Edited by Yūkei Matsunaga. Kyoto: Hozokan, pp. 219-38.

Fujita, Kōkan. 2000. Yugakai niokeru Huzen no Kōtei. Nihon Bukkyō Gakkai Nenpō 65: 107-25.

Geiger, Wilhelm. 1908. The Mahāvamsa. London: Published for the Pali Text Society by Oxford University Press.

Gethin, Rupert. 2004. Can Killing a Living Being ever be an Act of Compassion? The Analysis of the Act of Killing in the Abhidhamma and Pali Commentaries. Journal of Buddhist Ethics 11: 167-202.

Gethin, Rupert. 2007. Buddhist Monks, Buddhist Kings, Buddhist Violence: On the Early Buddhist Attitude to Violence. In Religion and Violence in South Asia: Theory and Practice. Edited by John R. Hinnells and Richard King. London and New York: Routledge, pp. 62-82.

Gray, David B. 2007. Compassionate Violence? On the Ethical Implications of Tantric Buddhist Ritual. Journal of Buddhist Ethics 14: 239-71.

Hara, Minoru. 2001. The Death of the Hero. Kokusai Bukkyōgaku Daigakuin Daigaku Kenkyū Kiyō (Journal of the International College for Advanced Buddhist Studies) 4: 1-26.

Harvey, Peter. 2000. An Introduction to Buddhist Ethics. Cambridge: Cambridge University Press.

Jamspal, Lozang. 2010a. The Range of the Bodhisattva, A Mahāyāna Sūtra (Byang chub sems dpa'i spyod yul) The Teaching of the Nirgrantha Satyaka, Critical Tibetan Edition. New York: The American Institute of Buddhist Studies, Columbia University Center for Buddhist Studies, and Tibet House US.

Jamspal, Lozang. 2010b. The Range of the Bodhisattva, A Mahāyāna Sūtra (Ārya-bhodhisattva-gocara) The Teaching of the Nirgrantha Satyaka, Introduction and Translation. New York: The American Institute of Buddhist Studies, Columbia University Center for Buddhist Studies, and Tibet House US.

Jenkins, Stephen. 2010. Making Merit through Warfare and Torture According to the Ārya-Bodhisattva-gocaraupāyavișaya-vikurvaṇa-nirdeśa Sūtra. In Buddhist Warfare. Edited by Michael Jerryson and Mark Juergensmeyer. Oxford: Oxford University Press, pp. 59-75.

Jenkins, Stephen. 2011. On the Auspiciousness of Compassionate Violence. Journal of the International Association of Buddhist Studies 3: 299-331.

Jenkins, Stephen. 2016. Debate, Magic, and Massacre: The High Stakes and Ethical Dynamics of Battling Slanderers of the Dharma in Indian Narrative and Ethical Theory. Journal of Religion and Violence 4: 129-57. [CrossRef] 
Jerryson, Michael. 2018. If You Meet the Buddha on the Road: Buddhism, Politics, and Violence. Oxford: Oxford University Press.

Mukhopadhyaya, Sujitkumar. 1963. The Aśokāvadāna: Sanskrit Text Compared with Chinese Versions. Delhi: Sahitya Akademi.

Murakami, Shinkan. 1996. Shyoki no Bukkyō niokeru Husesshō to Wahei no Shikō (The Principles of Non-killing and Peace in Early Buddhism). Nihon Bukkyō Gakkai Nenpō (Journal of the Nippon Buddhist Research Association) 61: 15-33.

Nagao, Gajin. 1987. Syō Daijō Ron: Aayaku to Chūkai. Tokyo: Kodansha, vol. 2.

Nakamura, Hajime, and Kyosho Hayajima. 1964. Milinda Ō no Toi. Tokyo: Heibonsha, vol. 2.

Okano, Kiyoshi. 2010. Shakuson ga Zense de Okashita Satsujin: Daijō Hōben Kyō ni yoru Sono Kaikyaku. Tetsugaku Nenpō (Annual of Philosophy Published by the Faculty of Humanities, Kyushu University) 69: 139-75.

Olivelle, Patrick. 2005. Manu's Code of Law: A Critical Edition and Translation of the Mānava-Dharmaśāstra. Oxford: Oxford University Press.

Pradhan, P. 1967. Abhidharmakośabhāṣya of Vasubandhu. Patna: First publ.

Rhys Davids, T. W. 1890. The Questions of King Milinda, Part I. Oxford: Clarendon Press.

Rhys Davids, T. W., and J. Estlin Carpenter. 1947. The Dīgha Nikāya. vol. II. London: Published for the Pali Text Society by Geoffrey Cumberlege, Oxford University Press. First published 1903.

Schmithausen, Lambert. 1999. Aspects of the Buddhist Attitude towards War. In Violence Denied: Violence, Non-violence and the Rationalization of Violence in South Asian Cultural History. Edited by E. M. Houben and K. R. Van Kooij. Leiden: Brill, pp. 45-67.

Sen, Amulyachandra. 1956. Asoka's Edicts. Institute of Indology Series, No. 7; Calcutta: The Indian Publicity Society.

Silk, Jonathan A. 2007. Good and Evil in Indian Buddhism: The Five Sins of Immediate Retribution. Journal of Indian Philosophy 35: 253-86. [CrossRef]

Silk, Jonathan A. 2013. The Proof is in the Pudding: What is Involved in Editing and Translating a Mahāyāna Sūtra? Indo-Iranian Journal 56: 157-78. [CrossRef]

Strong, John S. 1983. The Legend of King Aśoka: A Study and Translation of the Aśokāvadāna. Princeton: Princeton University Press.

Sugiki, Tsunehiko. 2018. Indo Daijō Bukkyō ni Mirareru Keibatsu Sensō Ron: Jūzen ha Donoyōni Ōsei toshite Tenkai Sarerunoka (A Buddhist View of Punishment and Warfare Found in the Indian Mahāyāna Satyakaparivarta: The Moral Characteristics of Kingship in Accordance with the Ten Good Deeds). Tōyō -Gakujutsu Kenkyū (The Journal of Oriental Studies) 181: 2-25.

Sugiki, Tsunehiko. 2020. An Aspect of Indian Buddhist Views of Capital Punishment and Severe Physical Punishment. Indogaku Bukkyōgaku Kenkyū (Journal of Indian and Buddhist Studies) 68. Forthcoming.

Tatz, Mark. 2016. The Skill in Means (Upāyakauśalya) Sūtra. Delhi: Motilal Banarsidass. First published 1994.

Tatz, Mark. 1986. Asanga's Chapter on Ethics with the Commentary of Tsong-Kha-Pa: The Basic Path to Awakening, the Complete Bodhisattva. Studies in Asian Thought and Religion. vol. 4, Lewiston: Queenston.

Tikhonov, Vladimir. 2013. Introduction: Dialectics of Violence and Non-violence - Buddhism and Other Religions. In Buddhism and Violence: Militarism and Buddhism in Modern Asia. Edited by Vladimir Tikhonov and Torkel Brekke. New York and London: Routledge, pp. 1-12.

Trenckner, V. 1993. The Majjhima-Nikāya, vol. I. Oxford: Pali Text Society. First published 1888.

Trenckner, V. 1962. The Milindapañho, Being Dialogues between King Milinda and the Buddhist Sage Nāgasena. London: Published for the Pali Text Society by Luzac.

Tsukamoto, Keishō. 1976. Ashoka Ō Hibun. Tokyo: Daisanbunmeisha.

Walshe, Maurice. 1987. The Long Discourses of the Buddha: A Translation of the Dīgha Nikāya. Boston: Wisdom Publications.

Zimmermann, Michael. 2000. A Mahāyānist Criticism of Arthaśāstra: The Chapter on Royal Ethics in the Bodhisattva-gocaropāya-vișaya-vikurvaṇa-nirdeśa-sūtra. Sōka Daigaku Kokusai Bukkyō Gaku Kōtō Kenkyū Jo Nenpō. Annual Report of the International Research Institute for Advanced Buddhology at Soka University for the Academic Year 1999. 3. Tokyo: International Research Institute for Advanced Buddhology, Soka University, pp. 177-211.

Zimmermann, Michael. 2006. Only a Fool Becomes a King: Buddhist Stances on Punishment. In Buddhism and Violence. Edited by Michael Zimmermann. Lumbini: Lumbini International Research Institute, pp. $213-42$. 
(C) 2020 by the author. Licensee MDPI, Basel, Switzerland. This article is an open access article distributed under the terms and conditions of the Creative Commons Attribution (CC BY) license (http://creativecommons.org/licenses/by/4.0/). 